
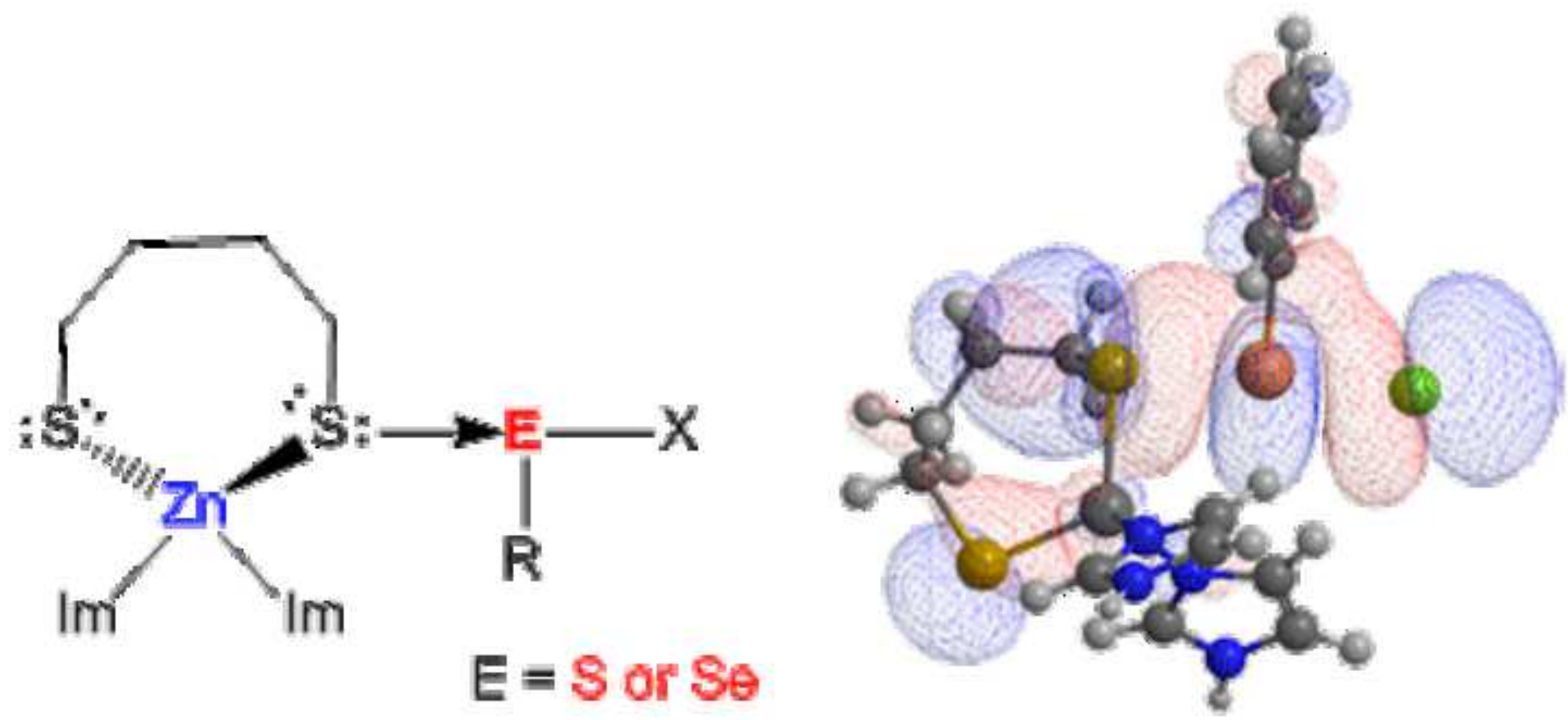
Synopsis:

Density functional theory calculations of the $\mathrm{S} \cdots \mathrm{S} / \mathrm{Se}$ chalcogen bonding interactions between reducible organosulfur and-selenium compounds are used to explore the potential for these compounds to release $\mathrm{Zn}^{2+}$ from zinc finger proteins. The strongest interactions are found Se over $\mathrm{S}$ and the $\mathrm{Cys}_{4}$-like models. 


\title{
Chalcogen bonding interactions between reducible sulfur and selenium compounds and models of zinc finger proteins
}

\author{
Patricia B. Lutz ${ }^{a}$ and Craig A. Bayse ${ }^{b} *$ \\ ${ }^{a}$ Department of Science, Technology and Mathematics, Regent University, Virginia Beach, Virginia \\ 23464 \\ ${ }^{b}$ Department of Chemistry and Biochemistry, Old Dominion University, Norfolk, Virginia 23529
}

\section{abstract}

Reducible sulfur and selenium ( $r$-S/Se) compounds, defined as sulfur and selenium compounds not in the lowest -2 oxidation state (e.g., -1 to +6 ), release $\mathrm{Zn}^{2+}$ from zinc-sulfur proteins such as zinc fingers (ZFs) and metallothionein. A series of density functional theory calculations were performed on donor-acceptor complexes between r-S/Se compounds and models of the $\mathrm{Cys}_{2} \mathrm{His}_{2}$, $\mathrm{Cys}_{3} \mathrm{His}$ and $\mathrm{Cys}_{4} \mathrm{ZF}$ sites. These $\mathrm{S} \cdots \mathrm{S} / \mathrm{Se}$ chalcogen bonding interactions consist of the donation of electron density from a S lone pair on the ZF model to a S/Se-X antibonding molecular orbital of the $\mathrm{r}-\mathrm{S} / \mathrm{Se}$ compound. The strength of the interaction was shown to be dependent upon the Lewis basicity of the ZF model $\left(\mathrm{Cys}_{4}>\mathrm{Cys}_{3} \mathrm{His}>\mathrm{Cys}_{2} \mathrm{His}_{2}\right.$ ) and the Lewis acidity of the $\mathrm{r}-\mathrm{S} / \mathrm{Se}$ compound as measured by the energy of the $\mathrm{S} / \mathrm{Se}-\mathrm{X}$ antibonding orbital. Interactions with the softer $\mathrm{r}-\mathrm{Se}$ compounds were stronger than the r-S compounds, consistent with the greater reactivity of the former with ZF proteins. 


\section{Introduction}

Redox signaling by zinc-sulfur proteins are involved in many cellular processes including replication, repair, transcription, translation, cell proliferation, apoptosis, metabolism, and signaling [1-8]. $\mathrm{Zn}^{2+}$ plays a structural role by tetrahedrally coordinating to 2-4 Cys residues in conjunction with His to ensure the correct folding of a zinc finger (ZF) motif required for interaction with DNA, RNA, proteins, or other molecules[1,2,9,10]. ZFs can be divided into three classes based on the number and type of residues involved in $\mathrm{Zn}^{2+}$ coordination: (1) $\mathrm{CCHH}$, where $\mathrm{Zn}^{2+}$ is coordinated to 2 Cys and $2 \mathrm{His}$, (2) CCCH, 3 Cys and $1 \mathrm{His}$, and (3) CCCC, 4 Cys (Fig. 1) $[2,3] . \mathrm{Zn}^{2+}$ itself is redox inactive, but oxidation of the Cys thiolates release $\mathrm{Zn}^{2+}$, causing the ZF to lose its secondary structure and its ability to bind DNA or RNA [1,11-14]. Similarly, the zinc storage protein metallothionein (MT), which reversibly binds $7 \mathrm{Zn}^{2+}$ in CCCC coordination, regulates cellular $\mathrm{Zn}^{+2}$ levels and trigger signaling pathways through Cys redox processes $[1,4,15]$. Proliferation of viruses and tumor cells could be inhibited by electrophilic compounds that release $\mathrm{Zn}^{2+}$ from conserved ZF motifs essential for replication (e.g., the nucleocapsid protein NCp7 (CCCH) of human immunodeficiency-1 virus (HIV-1) [16-18] and the E6 oncoprotein (CCCC) of the human papillomavirus (HPV) [19]) as a potential treatment mechanism [20-28].

Reducible sulfur and selenium ( $\mathrm{r}-\mathrm{S} / \mathrm{Se}$ ) compounds, defined as sulfur and selenium compounds not in the lowest -2 oxidation state (e.g., -1 to +6 ; 1-16 in Figure 2), release $\mathrm{Zn}^{2+}$ from various ZF proteins [29-39]. For example, the disulfides cystamine 1a and disulfiram 2 (oxidation state $=-1$ ) were able to release $\mathrm{Zn}^{2+}$ from NCp7, but the analogous thiols cysteamine 3 and dithiocarb 4 (oxidation state $=-2$ ) could not, even after prolonged incubation [40]. Dithiobenzamides (5, DIBAs) react with ZFs [29] and quickly cyclize in aqueous solution to benzisothiazolones $(6, \mathrm{BITAs})$ which unfold $\mathrm{NCp} 7$ through $\mathrm{Zn}^{2+}$ release $[41,42]$. BITAs are more active than the parent DIBAs and have been hypothesized to be the major contributor to antiviral activity [30]. DIBA compounds that release $\mathrm{Zn}^{2+}$ rapidly were found to be highly toxic, possibly through reactions with other cellular thiols [42]. The less reactive BITAs were much less

toxic and considered more promising as anti-viral chemotherapy agents [42]. Aldrithiol-2 (7a, AT-2), but not diphenyl disulfide 7 b, releases $\mathrm{Zn}^{2+}$ irreversibly from NCp7 under cellular 
conditions $[19,25,43-46]$ and has been studied to inactivate HIV-1 infectivity for vaccine development $[47,48]$.

Ebselen $\mathbf{6 b}$ and other $\mathbf{r}$-Se compounds, well-known for their antioxidant activity, also release $\mathrm{Zn}^{2+}$ from zinc-sulfur proteins and have potential as antiviral and anticancer agents [32,34-38]. $\mathrm{r}$-Se compounds also react faster than $\mathrm{r}$-S: selenocystamine $\mathbf{1 b}$ releases $\mathrm{Zn}^{2+}$ from MT faster than 1a.[34] $\mathrm{Zn}^{2+}$ release by selenite may explain how it suppresses tumor cell growth and activates apoptosis [35]. Selenocystine $\mathbf{8 b}$, along with benzeneselenenyl chloride $\mathbf{9}, \mathbf{6 b}, \mathbf{2 -}$ nitrophenylselenocyanate 12, and 13, inactivate the CCCC-type ZF DNA-repair proteins formamidopyrimidine-DNA glycosidase (Fpg) and xeroderma pigmentosum group A protein (XPA) to inhibit DNA binding [37]. Benzeneselenenic acid 13 (oxidation state 0) and benzeneseleninic acid 14 (oxidation state +2 ) release $\mathrm{Zn}^{2+}$ from MT even in the presence of a 200 to 500-fold excess of glutathione [34], but selenomethionine (oxidation state -2) was inactive [37]. 6b inhibits the binding of DNA to transcriptions factors TFIIIA and Sp1 (CCHH) [34,35]. 1,4-phenylenebis(methylene)selenocyanate 15 (p-XSC), a chemopreventive agent in many preclinical animal studies, inhibited DNA binding to transcription factors Sp1 and Sp2 $(\mathrm{CCHH})$ [49-51] and was proposed to target the CCCC-type DNA binding domain of the androgen receptor in prostate E6 cancer cells [19]. In constrast, the sulfur analogue of 15 had no effect on DNA binding to transcription factors [52].

The proposed mechanism for the release of $\mathrm{Zn}^{2+}$ involves the initial attack of the electrophilic r-S/Se compound on a ZF Cys sulfur. (Scheme 1) [39]. The r-S/Se compound (represented by $\mathrm{RE}-\mathrm{X}\left(\mathrm{E}=\mathrm{S}\right.$ or $\mathrm{Se}$ ) in scheme 1 ) transfers an $\mathrm{RE}^{+}$group to the Cys with loss of $\mathrm{X}^{-}$ to oxidize the thiolate to a disulfide or selenenylsulfide (e.g. 1a: $\mathrm{RE}^{+}=\mathrm{H}_{2} \mathrm{NCH}_{2} \mathrm{CH}_{2} \mathrm{~S}^{+}, \mathrm{X}^{-}=$ $\mathrm{H}_{2} \mathrm{NCH}_{2} \mathrm{CH}_{2} \mathrm{~S}^{-}$; 9: $\mathrm{RE}^{+}=\mathrm{PhSe}^{+}, \mathrm{X}^{-}=\mathrm{Cl}^{-}$). A chalcogen bonded donor-acceptor intermediate analogous to the ion-dipole complex proposed for the related thiol-disulfide exchange mechanism [53] may be formed along the pathway for initial electrophilic attack, especially in the case of the weaker electrophiles that are of greater interest as potential drugs. Sulfen/selenenation of Cys weakens its ability to coordinate to $\mathrm{Zn}^{2+}$ leading to its replacement in the coordination sphere by solvent. From this sulfen/selenenated intermediate, the ZF either undergoes (a) internal attack of a remaining Cys to form an intramolecular disulfide linkage 
$\left(\mathrm{ZF}_{\mathrm{ox}}\right)$ with release of thiolate or selenolate $(\mathrm{RE})$ or $(\mathrm{b})$ persulfen-/selenenation of the remaining Cys $\left(\mathrm{Zn}(\mathrm{S}-\mathrm{ER})_{\mathrm{n}}\right)$ by additional equivalents of $\mathrm{r}-\mathrm{S} / \mathrm{Se}$ compounds. The former appears to be preferred in CCHH-type proteins and the latter in CCCC ZFs and MT. When DIBAs and BITAs react with $\mathrm{NCp7}(\mathrm{CCCH})$, Loo et al. found apoproteins with intra- (Cys-Cys) and intermolecular (Cys-DIBA) disulfide bonds [41]. Oxidation of Cys thiolate ligand by any of these paths will destabilize the coordination of $\mathrm{Zn}^{2+}$ to the protein resulting in release of the ion and unfolding of $\mathrm{ZF}$. Selenolates $\mathrm{RSe}^{-}$released by disulfide formation to $\mathrm{ZF}_{\mathrm{ox}}$ can be oxidized by reactive oxygen species (ROS) to form R-SeOH, which can then react with other $\mathrm{ZFs}$ to catalyze $\mathrm{Zn}^{2+}$ release [54]. The $r-S$ compounds do not show the same catalytic potential due to the relative stabilities of selenenic and sulfenic acid [34,54].

Understanding how $\mathrm{r}-\mathrm{S} / \mathrm{Se}$ compounds can react with ZF proteins can guide the development of new chemopreventive, chemotherapeutic, and anti-viral agents. Density functional theory (DFT) has been used previously to explore the oxidation of ZF models by reactive oxygen species [55-58]. In this study, we expand upon earlier DFT studies on the interaction of r-Se compounds with CCHH ZF models $[39,59]$ to investigate the interaction of small $\mathrm{r}-\mathrm{S} / \mathrm{Se}$ compounds with models of all three classes of ZF proteins. Specifically, we explore the Lewis acid/base and hard/soft properties for the formation of an $\mathrm{S} / \mathrm{Se} \cdots \mathrm{S}$ interaction of a 'chalcogen-bonded' donor-acceptor complex as a measure for the potential for $\mathrm{Zn}^{2+}$ release by an $\mathrm{r}-\mathrm{S} / \mathrm{Se}$ compound.

\section{Theoretical Methods}

DFT geometry optimizations and frequency calculations were performed using Gaussian09 [60] with the PW91TPSS functional. PW91 is the exchange component of Perdew and Wang's 1991 functional[61] and TPSS is the r-dependent gradient-corrected correlation functional of Tao, Perdew, Staroverov, and Scuseria [62]. This combination of functionals was found to be one of the best performing functionals of those available in Gaussian 09 for geometries and interaction energies of non-covalent interactions [63]. Dunning's split-valence triple- $\zeta$ basis set augmented with polarization functions (TZVP) was used for $\mathrm{C}, \mathrm{N}, \mathrm{O}$ and $\mathrm{H}$, with additional diffuse $s$ and $p$ functions on $C, N$ and $O$ [64]. $Z n$ was represented by the Hurley et al. 
relativistic effective core potential (RECP) basis set augmented with a set of $s, p$, and d diffuse and polarization functions [65]. The Wadt-Hay ECP basis set augmented with a set of $s$ and $p$ functions was used for $\mathrm{S}, \mathrm{Se}$ and $\mathrm{Cl}$ [66]. All structures are minima on the potential energy surface as characterized by vibrational analysis. Relative energies of formation for the complexes were calculated and corrected for zero-point energies ( $\triangle \mathrm{E}+\mathrm{ZPE})$. The Natural Bond Orbital (NBO) program version 3.1 was used to calculate Wiberg bond indices (WBIs)[67] and the natural population analysis (NPA) charges. The WBI, a measure of the bonding interaction between two atoms, is the sum of the squares of the off-diagonal elements of the density matrix, $\mathrm{P}$, between pairs of atoms in the NAO basis (Equation 1).

$$
W B I_{A B}=\sum_{p \in A} \sum_{q \in B} P_{p q}^{2}
$$

Several parameters were estimated from the DFT(PW91TPSS) HOMO and LUMO energies to estimate the affinity of the $\mathrm{r}-\mathrm{S} / \mathrm{Se}$ compounds to model ZFs. The softness parameter $\sigma$ is calculated as the inverse of the hardness $\eta[68,69]$, defined as the second derivative of the electronic energy $(E)$ with respect to the number of electrons $N$ at external potential $v(r)$, which reduces to half the difference of the ionization potential (IP) and electron affinity (EA). In the calculation of $\sigma$, the IP and EA have been estimated as the HOMO energy and vertical electron affinity, respectively (eq 2 ).

$$
\eta=\frac{1}{\sigma}=\frac{1}{2}\left(\frac{\partial^{2} E}{\partial N^{2}}\right)_{v}=\frac{I P-E A}{2}
$$

\section{Results and discussion}

An $\mathrm{S} / \mathrm{Se} \cdots \mathrm{S}$ interaction formed between an $\mathrm{r}$-S/Se compound and the ZF can be described in a similar fashion to previous models of Se $\cdots \mathrm{N}, \mathrm{O}$ donor-acceptor interactions more recently classified as chalcogen bonds [70-72]. In terms of valence bond theory, the interaction of a Lewis base, like the thiolate lone pair, with the Lewis acidic S/Se-X group can be written in 
terms of the resonance structures in Scheme 2a. Strongly basic donors will increase contribution of the right-hand resonance structure $B$ and if the donor is similar in strength to the $X$ group, the interaction may expand the octet of $S / S e$ to result in a linear L-S/Se-X 3c4e bond as in a hypervalent molecule (C). Lewis bases that are even stronger may shift the dominant resonance structure to $B$ for net nucleophilic substitution. In terms of molecular orbital theory, the ZF thiolate lone pair MO mixes with the $\mathrm{S} / \mathrm{Se}-\mathrm{X}$ antibonding $\mathrm{MO}\left(\phi^{*}{ }_{\mathrm{s} / \mathrm{Se}-\mathrm{x}}\right)$ of the $\mathrm{r}-\mathrm{S} / \mathrm{Se}$ compound (Scheme $2 \mathrm{~b}$ ). The incoming thiolate is nearly collinear to the leaving group $X$ to maximize overlap of the thiolate lone pair orbital and $\phi^{*}$ s/se- $x$. The smaller the difference in energy between this antibonding orbital and the donor $\mathrm{MO}$, the stronger the donor-acceptor interaction will be. As a result, weak S/Se-X bonds will be more Lewis acidic because their lowlying antibonding orbitals will be better able to combine with the donor orbital. In this model, the delocalization of the ZF thiolate charge into the $\phi^{*} \mathrm{~s} / \mathrm{Se}-\mathrm{x}$ orbital increases $\mathrm{S} / \mathrm{Se}-\mathrm{S}_{\mathrm{ZF}}$ bonding at the expense of the S/Se-X bond, leading to full S/Se-S $\mathrm{SF}_{\mathrm{ZF}}$ bond formation with $\mathrm{S} / \mathrm{Se}-\mathrm{X}$ and $\mathrm{Zn}-\mathrm{S}$ bond cleavage in extreme cases. The interaction of $\mathrm{r}-\mathrm{S} / \mathrm{Se}$ compounds with ZFs could be alternatively formulated as the competition between the $\mathrm{r}-\mathrm{S} / \mathrm{Se}$ electrophile and the $\mathrm{Zn}^{2+}$ ion. From this viewpoint, electrophiles more Lewis acidic than $\mathrm{Zn}^{2+}$ would form stronger donoracceptor interactions capable of releasing the ion from a ZF.

In this study, we investigate the trends in the interactions of $r-S / S e$ compounds with small models of the three ZF classes constructed to represent only the Cys and His ligands. DFT studies by Topol et al. found Cys and His to be responsible for the bulk of the free energy of metal binding, with other residues contributing only marginally [73]. In our models, His was replaced with neutral imidazole (Im) ligands. Pairs of Cys were modeled as 1,4-

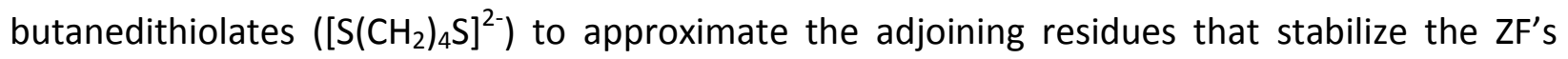
structure. The third Cys in the $\mathrm{CCCH}$ model was represented with methyl thiolate. Previous work has suggested that ZF Cys ligands can be protonated, or that hydrogen bonding can modify the nucleophilicity of ZFs [74-77]. The ZF models in this study have omitted these features due to the wide variability found in ZF motifs to order to examine the baseline effect of interactions with the ZF core. 
Bond distances for the DFT(PW91TPSS)-optimized geometries of the resulting models $\left[\mathrm{Zn}(\mathrm{Im})_{2}\left(\mathrm{~S}\left(\mathrm{CH}_{2}\right)_{4} \mathrm{~S}\right)\right] \mathrm{Zn}-\mathrm{CCHH},\left[\mathrm{Zn}(\mathrm{Im})(\mathrm{SMe})\left(\mathrm{S}\left(\mathrm{CH}_{2}\right)_{4} \mathrm{~S}\right)\right]^{-} \mathrm{Zn}-\mathrm{CCCH}$, and $\left[\mathrm{Zn}\left(\mathrm{S}_{(}\left(\mathrm{CH}_{2}\right)_{4} \mathrm{~S}\right)_{2}\right]^{2-} \mathrm{Zn}-\mathrm{CCCC}$ were comparable to values measured from structures deposited in the Protein Data Bank (see Fig. 1 and 3) [78]. The Zn-S bond distances increase with the number of sulfur atoms coordinated to $\mathrm{Zn}^{2+}$ due to steric interactions and electrostatic repulsions between the thiolates. The WBI for the Zn-S1 bond decreases linearly from Zn-CCHH to Zn-CCCC (Table 1) suggesting a weakening of the bond. The Lewis basicity of the ZF models increases with the number of Cys ligands $(\mathbf{Z n - C C H H}<\mathbf{Z n - C C C H}<\mathbf{Z n - C C C C})$, as demonstated by the destabilization of the HOMO energy and increase in the partial charges on the sulfur centers (Table 1). Similarly, Topol found the DFT ionization potential of ZF models to decrease as the number of thiolates coordinated to the $\mathrm{Zn}^{2+}$ increased [73]. The HOMO of each ZF model has thiolate 3p character consistent with the lone-pairs perpendicular to the Zn-S-C plane (Fig. 3). From ZnCCHH to $\mathrm{Zn}$-CCCC, the charge on the $\mathrm{Zn}^{2+}$ becomes less positive as more thiolate ligands donate electron density to $\mathrm{Zn}^{2+}$ (Table 1 ). The softness $(\sigma)$ also increases with the number of thiolates coordinated to $\mathrm{Zn}^{2+}$, suggesting that the affinity of ZFs model for soft electrophiles like the $r$ $\mathrm{S} / \mathrm{Se}$ compounds is expected to be greatest for CCCC-type proteins.

The Lewis acidities of $r-S / S e$ compounds 5-14 and 16 were measured by the $\phi^{*} s / \mathrm{se-x}$ energy and the softness parameter calculated from their DFT(PW91TPSS)-optimized structures (Table S1). The $\phi^{*}$ s/se-x MO (examples in Fig 4 ) is generally the LUMO, with the exception of $6 a$ (LUMO+1), 7a (LUMO+2) and $\mathbf{1 2}(L U M O+4)$ due to the strength of the disulfide bond and the intramolecular interaction with the nitro group, in the latter case. A low energy $\phi^{*} \mathrm{~s} / \mathrm{se}-\mathrm{x}$ indicates an unstable $\mathrm{S} / \mathrm{Se}-\mathrm{X}$ bond that should readily accept electron density from lone pairs of the ZF models or other donors. The selenenyl chlorides $\mathbf{9}$ and $\mathbf{1 0}$ had the lowest $\phi^{*}{ }_{\mathrm{s} / \mathrm{s}-\mathrm{x}}$ energy and were the functional group with the highest overall softness (Fig. 5 and Table S1), and are expected to have the strongest donor-acceptor interaction with the soft ZF models. The compounds with the next lowest $\phi^{*} s / \mathrm{se}-\mathrm{x}$ energy are bisbenzamides $\mathbf{5 a}$ and $\mathbf{5 c}$ where the electron withdrawing amide groups stabilize $\phi^{*} s / \mathrm{se}-\mathrm{x}$ such that they are much better electrophiles than other disulfides/diselenides included in the study (contrast with $\mathbf{7}$ and $\mathbf{8}$ ). The Se-N bond of the selenenamides $6 \mathrm{c}-\mathrm{d}$ are also indicative of good electrophiles. The $\phi^{*}{ }_{\mathrm{s} / \mathrm{s}-\mathrm{x}}$ of 14 
is only slightly higher in energy than $\mathbf{1 3}$, suggesting a similar ZF affinity between the oxidation states, with the seleninic acid able to react with more equivalents of thiolate. The donation of the nitro group to the $\phi^{*}{ }_{\text {Se-cN }}$ MO of $\mathbf{1 2}$ destabilizes the acceptor MO relative to $\mathbf{1 1}$. Generally, $r$-Se compounds have lower $\phi^{*} s / \mathrm{se-x}$ energies and are softer than their sulfur analogues, and are thus expected to interact more strongly with ZFs (compare $\mathbf{6 b}$ and $\mathbf{6 d}$ (Fig. 5)). The softness parameters for $\mathbf{5}$ and $\mathbf{6}$ are similar in magnitude to values found for a set of disulfides and sulfenamides in a related study of the correlation of molecular properties to experimental reaction rates of $\mathrm{Zn}^{2+}$ release from the NCp7 CCCH ZFs [33].

Donor-acceptor complexes between the $\mathrm{r}-\mathrm{S} / \mathrm{Se}$ compounds with the ZF models were optimized at the DFT(PW91TPSS) level to model the proposed initial S/Se $\cdots S$ interaction (Schemes 1 and 2). The interaction energies for the formation of the chalcogen-bonded intermediate in scheme 1 ( $Z F+R E-X \rightarrow \operatorname{lnt}$ ) were corrected for zero-point energies $(\triangle E+Z P E$; Table S2) and comparable to previous results [39]. As expected from the bonding model, the $\triangle E+Z P E$ of each $r-S / S e$ compound (with the exception of 16a) increased with the Lewis basicity of the ZF model, Zn-CCHH $<$ Zn-CCCH $<$ Zn-CCCC (Fig. 6a). The donor-acceptor MO (Fig 7) formed by the interaction is also stabilized relative to the HOMO of the complex as the basicity of the ZF model increases (e.g., $0.22 \mathrm{eV}$ (13-Zn-CCHH), $0.94 \mathrm{eV}$ (13-Zn-CCCH), $1.00 \mathrm{eV}$ (13-Zn(CCC)). This trend is consistent with the greater reactivity of model complexes toward electrophilic attack by alkylating agents as the number of zinc-bound thiolates is increased $[79,80]$. The interaction strength increases as the $\phi^{*}$ s/se-x $M O$ is stabilized and can better overlap with the HOMOs of the ZF models (e.g., Fig. $6 \mathrm{~b}$ for $\mathbf{Z n}$-CCHH complexes) as expected from the bonding model (scheme 2b). Similarly the softness parameters $\sigma$ of the $r-S / S e$ compounds generally correlate with $\triangle \mathrm{E}+\mathrm{ZPE}$ (e.g., Fig. $6 \mathrm{c}$ for the $\mathrm{Zn}$-CCHH model) demonstrating a higher affinity of the ZF models for softer Lewis acids. The strongest interactions are found for the selenenyl chlorides 9 and 10, consistent with the low energy $\phi^{*}$ s/se-x MO of the Se-Cl bond, often leading to Se-Cl bond cleavage (vide infra). The Se-N bonds of $\mathbf{6 c}$ and $\mathbf{6 d}$ and the activated Se-Se bonds for $\mathbf{5 c}$ and $\mathbf{8 b}$ also have high affinities for the ZF model complexes. Sulfur analogues consistently form weaker interactions than the softer selenium derivatives; for example, the sulfur analogue of ebselen $\mathbf{6 b}$ binds to the ZF models 9 - 
$14 \mathrm{kcal} / \mathrm{mol}$ more weakly than ebselen $\mathbf{6 d}$ (Table S2). Interactions with disulfides are generally the weakest with the exception of $5 \mathbf{a}$ and $\mathbf{8 a}$. In 12, the intramolecular Se $\cdots 0$ interaction with the nitro group destabilizes the $\phi^{*}$ s/se-x $\mathrm{MO}$ and must be displaced by the ZF thiolate in order for the Se...S interaction to occur, resulting in an overall weak interaction.

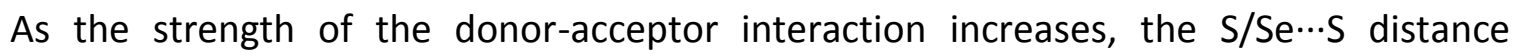
shortens and the bond to the leaving group $\mathrm{X}$ is weakened and elongated by the donation into $\phi^{*}$ s/Se-x (Tables S1 and S2). For example, in the interaction of 13 with the ZF models (Fig 7), the Se-..S interaction shortens from $2.83 \AA$ with $\mathbf{Z n}-\mathbf{C C H H}$ to $2.59 \AA$ with $\mathbf{Z n}-\mathbf{C C H H}$ as the Se-OH bond increases by $0.16 \AA$ over the series. Additionally, the Zn-S1 bond length also increases due to the reduction in the negative charge on S1 (i.e., $\mathrm{q}_{\mathrm{s} 1}=0.07 \mathrm{e}(\mathbf{1 3 - Z n - C C H H}), 0.15 \mathrm{e}(\mathbf{1 3 - Z n -}$ $\mathbf{C C C H})$ and $0.19 \mathrm{e}(\mathbf{1 3 - Z n - C C C C}))$. The shorter, stronger S/Se $\cdots S$ interactions are reflected in the larger S/Se-S1 WBI values, indicative of increased electron density in the chalcogen bonding interaction (Fig 6d). The S/Se-S1 WBI values also generally correlate to $\triangle E+Z P E$ for the $S / S e \cdots S$ interactions with $\mathbf{Z n}-\mathbf{C C H H}$, consistent with increased bonding in stronger donor-acceptor complexes (Fig. 6e). The lower $\triangle \mathrm{E}+\mathrm{ZPES}$ of the $\mathrm{r}$-Se compounds (Fig. 8) are due to the less stable Se-X bonds with lower energy $\phi^{*}$ s/Se-X MOs relative to analogous S-X bonds (Fig $5 \mathrm{c}$ ). Selenium is larger and more polarizable (softer) Lewis acid than sulfur, making it a better electrophile for the soft Lewis base ZF models.

The dimethyl compounds $16 \mathrm{a}-\mathrm{c}$ are poor acceptors due to their strong S/Se-X bonds and higher energy $\phi^{*}$ s/se-x orbitals (Fig. 9). Although they would be predicted to be less reactive with the ZF models, they provide a baseline for comparing the interaction of dichalcide bonds with ZFs in the absence of electronic or steric effects. No S...S interaction could be found for the interaction of 16a with Zn-CCHH (Fig. 9) in agreement with its weak Lewis acidity. Several S $\cdots H$ $\mathrm{C}$ interactions account for the stronger interaction energy of $16 \mathrm{a}-\mathbf{Z n}-\mathbf{C C H H}$ relative to $16 \mathrm{a}-\mathrm{Zn}$ $\mathbf{C C C H}$. The diselenide $\mathbf{1 6 b}$ would be predicted to have the strongest interaction with the ZF models because it has the lowest energy $\phi^{*} \mathrm{~s} / \mathrm{se}-\mathrm{x}$, is softer, and $\mathrm{RSe}^{-}$is more polarizable and a better leaving group. Although $\mathbf{1 6 b}$ forms the most stable interaction with Zn-CCCC, selenenylsulfide $\mathbf{1 6 c}$ forms the strongest interactions with $\mathbf{Z n}-\mathbf{C C H H}$ and $\mathbf{Z n - C C C H}$ due to the polarization of the Se-S bond $\left(q_{s e}=0.209 e\right.$ and $\left.q_{s}=0.007 e\right)$ and the higher affinity of the MeSe ${ }^{+}$ 
for the softer thiolate of the ZF model versus the free MeS- These results suggest that selenenylsulfide derivatives may be better reagents than diselenides for $\mathrm{Zn}^{2+}$ release, although r-Se compounds such as diselenides are likely converted to selenenyl sulfides in the presence of thiols $[32,81]$.

In a number of cases, the high Lewis basicity of the $\mathbf{Z n - C C C H}$ or $\mathbf{Z n - C C C C}$ models in combination with an $\mathrm{r}$-S/Se compound with moderate to high Lewis acidity shifted the dominant resonance structure to $B$ (scheme $2 \mathrm{a}$ ) resulting in $\mathrm{S} / \mathrm{Se}-\mathrm{X}$ bond breakage. For example, in the interaction of $\mathbf{9}$ with $\mathbf{Z n}-\mathbf{C C C H}$ (Fig 10), Se-S1 bond formation oxidizes the thiolate, which breaks the coordinate covalent bond to $\mathrm{Zn}^{2+}$, causing its coordination to change from tetrahedral to trigonal planar (Fig. 9). Similarly, the interaction of $\mathbf{6 d}$ with Zn-CCCC $(\triangle E+Z P E=-64.7 \mathrm{kcal} / \mathrm{mol})$ has bond formation between S1 and Se, and S1 has left the $\mathrm{Zn}^{2+}$ coordination sphere (Fig. 10). The Se-N bond, though weakened, is not broken, leading to an NSe-S1 hypervalent bond (i.e., C in scheme 2a). In a DFT study of $\mathbf{6 d}$ with a model similar to $\mathbf{Z n -}$ $\mathbf{C C H H}$, a three water network was added to the initial Se $\cdots$ S donor-acceptor complex to supply a proton for Se-N bond breaking simultaneous with Se-S bond formation [59]. Se-X bond breaking in these gas phase calculations implies that $\mathbf{6 d}, \mathbf{9}$, and 10 would be expected to rapidly release $\mathrm{Zn}^{2+}$ from a CCCC-type ZF. However, this tendency to shift the dominant resonance structure to B could be attributed to the absence of solvation or hydrogen bonding interactions to stabilize the negative charge of the thiolate ligands of the $\mathrm{CCCH}$ and $\mathrm{CCCC}$ model complexes.

Our DFT results are in reasonable agreement with available experimental data for $\mathrm{Zn}^{2+}$ release by $\mathrm{r}$-S/Se compounds with some discrepancies due to the limitations of the model complexes. For example, $\mathbf{5 a}$ and $\mathbf{6 b}$ have been shown to release between 25 to $75 \%$ of $\mathrm{Zn}^{2+}$ from $\mathrm{NCp} 7(\mathrm{CCCH})$, where $\mathbf{7 b}$ is unreactive $[25,42]$. $5 \mathbf{a}$ and $\mathbf{6 b}$ form strong $\mathrm{S} \cdots \mathrm{S}$ interactions with all ZF models due to their low energy $\phi^{*}{ }_{s / \mathrm{Se}-\mathrm{x}} \mathrm{MOs}$, but 7b with its low Lewis acidity only interacts strongly with Zn-CCCC (Fig S1). Experimentally, 7a releases $60 \%$ of $\mathrm{Zn}^{2+}$ from the E6 CCCC-type ZF, while $\mathbf{7 b}$ and $\mathbf{8 a}$ release only 15 and 12\%, respectively [19]. The DFT complexes of Zn-CCCC with 7a and 8a undergo bond breaking of their disulfide bonds ( $B$ in scheme $2 a$ ) while 7b forms the hypervalent $\mathbf{C}$, all consistent with the ability of these molecules to react with the protein. AT-2 (7a) was found to be reactive with the NCp7 CCCH ZF, but had no or weak activity 
against $\mathrm{CCHH}$ and CCCC ZFs [25,82], consistent with the stronger interaction of 7a with the $\mathrm{Zn}$ $\mathbf{C C C H}$ model relative to $\mathbf{Z n}-\mathbf{C C H H}$. These results suggest that some weakly oxidizing agents can selectively react with $\mathrm{CCCH}$ ZFs, but not with $\mathrm{CCHH}$ due to its weak basicity or CCCC due to modulation of Cys nucleophilicity through interactions with the protein. Jacob et al. found that rSe compounds were better able to release $\mathrm{Zn}^{2+}$ from MT than their sulfur counterparts [32]. Blessing et al. found that while $\mathbf{8 b}$ and $\mathbf{1 4}$ inhibited Fpg activity, their sulfur analogues did not, even at high concentrations [37]. Experimentally, Blessing et al. found $6 \mathbf{d}$, to be the most effective at inhibiting the activity of Fpg (CCCC), followed by 9, 12, 14, and 8b, but found 12 better able to release $\mathrm{Zn}^{2+}$ from a CCCC-type fragment of XPA than $\mathbf{8 b}>\mathbf{1 4}>\mathbf{6 d}>\mathbf{9}$ [37]. Our DFT calculations found $\mathbf{6 d}$ to have the highest interaction energy $(-63.0 \mathrm{kcal} / \mathrm{mol})$ with $\mathbf{Z n}-\mathbf{C C C C}$ followed by $\mathbf{8 b}(-52.3 \mathrm{kcal} / \mathrm{mol}) .6 \mathrm{~b}, \mathbf{8 b}$ and $\mathbf{9}$ are predicted to be highly reactive, each showing Se-S1 bond formation and S1-Zn dissociation with Zn-CCCC. 12 and 14 ( -26 kcal/mol) are predicted to interact strongly with CCCC-type ZFs, but not to the same extent as $\mathbf{6 b} \mathbf{b} \mathbf{8} \mathbf{b}$ and $\mathbf{9}$. Thus, the differences between the two sets of experimental results and the bonding trends for the ZF-r-S/Se model complexes can be attributed to the absence of key features of the protein, such as tuning of the ZF nucleophilicity through hydrogen bonding or protonation of the thiolates, or steric effects of the surrounding residues that limit accessibility of the ZF thiolates [82]. These features could also serve to stabilize or destabilize the donor-acceptor complex to facilitate or disfavor release of $\mathrm{Zn}^{2+}$ from the protein.

\section{Conclusions}

Electrophilic reagents such as reducible sulfur and selenium ( $r-\mathrm{S} / \mathrm{Se}$ ) compounds are important as potential anticancer and antiviral drugs. The interaction of $r-S / S e$ compounds with the zinc bound thiolates of three classes of zinc fingers was investigated using density functional theory. In general, increasing the number of thiolates coordinated to $\mathrm{Zn}^{2+}(2<3<4$ thiolates) led to stronger intermolecular S/Se $\cdots S$ interactions in a hypothetical intermediate for the initial attack of an $\mathrm{r}$-S/Se compound on a zinc finger protein. The trends for the complexation of the $\mathrm{r}-\mathrm{S} / \mathrm{Se}$ compounds are consistent with lowering of the energy of the acceptor $\phi^{*}$ s/se-x molecular orbital and the softness of the zinc-sulfur electrophile. This 
correlation of $\phi^{*} \mathrm{~s} / \mathrm{se}-\mathrm{x}$ with the interaction energy suggests that the therapeutic potential of an $r-S / S e$ compound to oxidize zinc finger proteins could be screened using its $\phi^{*}$ s/se-x energy. Selenium-containing compounds are predicted to interact most strongly due to their weak Se-X bonds and higher polarizibility. $\mathrm{S} / \mathrm{Se} \cdots \mathrm{S}$ intermediates could not be found in pairings of strong donors and acceptors consistent with the rapid release of $\mathrm{Zn}^{2+}$ in analogous experimental studies. In future work, models that include larger fragments of the protein from each of the classes will be explored to account for the stabilization of the thiolate lone pairs/highest occupied molecular orbital through hydrogen bonding to the protein backbone or protonation, accessibility to the Cys and other features of the protein.

\section{Acknowledgements}

This work was funded by the National Science Foundation (CHE-0750413). Calculations were performed using the Turing High Performance Cluster maintained by ODU Information Technology Services.

\section{References}

[1] W. Maret, Biochemistry (Mosc.) 43 (2004) 3301-3309.

[2] S.S. Krishna, I. Majumdar, N.V. Grishin, Nucleic Acids Res. 31 (2003) 532-550.

[3] W. Maret, Antioxid. Redox Signal. 8 (2006) 1419-1441.

[4] A. Krezel, Q. Hao, W. Maret, Arch. Biochem. Biophys. 463 (2007) 188-200.

[5] W. Maret, J. Biol. Inorg. Chem. 16 (2011) 1079-1086.

[6] K.-D. Kröncke, Arch. Biochem. Biophys. 463 (2007) 183-187.

[7] K.-D. Kröncke, L.-O. Klotz, Antioxid. Redox Signal. 11 (2009) 1015-1027.

[8] J.M. Berg, Y. Shi, Science 271 (1996) 1081-1085.

[9] N.P. Pavletich, C.O. Pabo, Science 252 (1991) 809-817.

[10] M.S. Lee, G.P. Gippert, K.V. Soman, D.A. Case, P.E. Wright, Science 245 (1989) 635-637.

[11] X. Liang, B. Lu, G.K. Scott, C.-H. Chang, M.A. Baldwin, C.C. Benz, Mol. Cell. Endocrinol. 146 (1998) 151161.

[12] S.-H. Lee, W. Maret, Antioxid. Redox Signal. 3 (2001) 531-534.

[13] M.A. Baldwin, C.C. Benz, Methods Enzymol. 353 (2002) 54-69.

[14] J.L. Larabee, J.R. Hocker, J.S. Hanas, Arch. Biochem. Biophys. 434 (2005) 139-149.

[15] L.-J. Jiang, W. Maret, B.L. Vallee, Proc. Natl. Acad. Sci. 95 (1998) 3483-3488.

[16] C. Bampi, S. Jacquenet, D. Lener, D. Décimo, J.-L. Darlix, Int. J. Biochem. Cell Biol. 36 (2004) 1668-1686.

[17] T. Dorfman, J. Luban, S.P. Goff, W.A. Haseltine, H.G. Göttlinger, J. Virol. 67 (1993) 6159-6169.

[18] E.O. Freed, Virology 251 (1998) 1-15.

[19] W. Beerheide, H.-U. Bernard, Y.-J. Tan, A. Ganesan, W.G. Rice, A.E. Ting, J. Natl. Cancer Inst. 91 (1999) 1211-1220.

[20] A.I. Anzellotti, N.P. Farrell, Chem. Soc. Rev. 37 (2008) 1629.

[21] C.C. Garcia, E.B. Damonte, Infect. Disord. - Drug Targets 7 (n.d.) 204-212.

[22] D.J.D. Reeves, A.J. Piefer, Drugs 65 (2012) 1747-1766.

[23] T.L. Hartman, R.W. Buckheit, Mol. Biol. Int. 2012 (2012) e401965. 
[24] A. Engelman, P. Cherepanov, Nat. Rev. Microbiol. 10 (2012) 279-290.

[25] I.A. Topol, C. McGrath, E. Chertova, C. Dasenbrock, W.R. Lacourse, M.A. Eissenstat, S.K. Burt, L.E. Henderson, J.R. Casas-Finet, Protein Sci. 10 (2001) 1434-1445.

[26] S.M. Quintal, Q.A. dePaula, N.P. Farrell, Metallomics 3 (2011) 121-139.

[27] Y.-M. Lee, Y.-T. Wang, Y. Duh, H.S. Yuan, C. Lim, J. Am. Chem. Soc. 135 (2013) 14028-14031.

[28] L.H. Wang, X.Y. Yang, X. Zhang, K. Mihalic, Y.-X. Fan, W. Xiao, O.M.Z. Howard, E. Appella, A.T. Maynard, W.L. Farrar, Nat. Med. 10 (2004) 40-47.

[29] W.G. Rice, J.G. Supko, L. Malspeis, R.W. Buckheit, D. Clanton, M. Bu, L. Graham, C.A. Schaeffer, J.A. Turpin, J. Domagala, R. Gogliotti, J.P. Bader, S.M. Halliday, L. Coren, R.C. Sowder, L.O. Arthur, L.E. Henderson, Science 270 (1995) 1194-1197.

[30] J.M. Domagala, J.P. Bader, R.D. Gogliotti, J.P. Sanchez, M.A. Stier, Y. Song, J.V.N. Vara Prasad, P.J. Tummino, J. Scholten, P. Harvey, T. Holler, S. Gracheck, D. Hupe, W.G. Rice, R. Schultz, Bioorg. Med. Chem. 5 (1997) 569-579.

[31] C. Jacob, W. Maret, B.L. Vallee, Proc. Natl. Acad. Sci. 95 (1998) 3489-3494.

[32] C. Jacob, W. Maret, B.L. Vallee, Biochem. Biophys. Res. Commun. 248 (1998) 569-573.

[33] A.T. Maynard, M. Huang, W.G. Rice, D.G. Covell, Proc. Natl. Acad. Sci. 95 (1998) 11578-11583.

[34] C. Jacob, W. Maret, B.L. Vallee, Proc. Natl. Acad. Sci. U. S. A. 96 (1999) 1910 -1914.

[35] J.L. Larabee, J.R. Hocker, R.J. Hanas, F.M. Kahn, J.S. Hanas, Biochem. Pharmacol. 64 (2002) 1757-1765.

[36] N.M. Giles, N.J. Gutowski, G.I. Giles, C. Jacob, FEBS Lett. 535 (2003) 179-182.

[37] H. Blessing, S. Kraus, P. Heindl, W. Bal, A. Hartwig, Eur. J. Biochem. 271 (2004) 3190-3199.

[38] J.L. Larabee, J.R. Hocker, J.S. Hanas, J. Inorg. Biochem. 103 (2009) 419-426.

[39] C.A. Bayse, S.M. Whitty, S. Antony, Curr. Chem. Biol. 7 (2013) 57-64.

[40] N.B. McDonnell, R.N. De Guzman, W.G. Rice, J.A. Turpin, M.F. Summers, J. Med. Chem. 40 (1997) 19691976.

[41] J.A. Loo, T.P. Holler, J. Sanchez, R. Gogliotti, L. Maloney, M.D. Reily, J. Med. Chem. 39 (1996) 4313-4320.

[42] P.J. Tummino, P.J. Harvey, T. McQuade, J. Domagala, R. Gogliotti, J. Sanchez, Y. Song, D. Hupe, Antimicrob. Agents Chemother. 41 (1997) 394-400.

[43] D.E. Ott, S.M. Hewes, W.G. Alvord, L.E. Henderson, L.O. Arthur, Virology 243 (1998) 283-292.

[44] M.S. Boukhvalova, G.A. Prince, J.C. Blanco, Virol. J. 7 (2010) 20.

[45] E. Chertova, B. Crise, D. Morcock, J. Bess, Jr., L. Henderson, J. Lifson, Curr. Mol. Med. 3 (2003) 265-272.

[46] C.C. García, M. Djavani, I. Topisirovic, K.L.B. Borden, M.S. Salvato, E.B. Damonte, J. Gen. Virol. 87 (2006) $1217-1228$.

[47] J.L. Rossio, M.T. Esser, K. Suryanarayana, D.K. Schneider, J.W. Bess, G.M. Vasquez, T.A. Wiltrout, E. Chertova, M.K. Grimes, Q. Sattentau, L.O. Arthur, L.E. Henderson, J.D. Lifson, J. Virol. 72 (1998) 7992-8001.

[48] L.O. Arthur, J.W. Bess, E.N. Chertova, J.L. Rossio, M.T. Esser, R.E. Benveniste, L.E. Henderson, J.D. Lifson, Aids Res. Hum. Retroviruses 14 (1998) S311-S319.

[49] K. El-Bayoumy, A. Das, B. Narayanan, N. Narayanan, E.S. Fiala, D. Desai, C.V. Rao, S. Amin, R. Sinha, Carcinogenesis 27 (2006) 1369-1376.

[50] K. El-Bayoumy, R. Sinha, Mutat. Res. Mol. Mech. Mutagen. 551 (2004) 181-197.

[51] K. El-Bayoumy, C.V. Rao, B.S. Reddy, Nutr. Cancer 40 (2001) 18-27.

[52] B.W. Youn, E.S. Fiala, O.S. Sohn, Nutr. Cancer 40 (2001) 28-33.

[53] M. Paranjothy, M.R. Siebert, W.L. Hase, S.M. Bachrach, J. Phys. Chem. A 116 (2012) 11492-11499.

[54] Y. Chen, W. Maret, Antioxid. Redox Signal. 3 (2001) 651-656.

[55] R. Kassim, C. Ramseyer, M. Enescu, Inorg. Chem. 50 (2011) 5407-5416.

[56] R. Kassim, C. Ramseyer, M. Enescu, JBIC J. Biol. Inorg. Chem. 18 (2013) 333-342.

[57] M. Enescu, R. Kassim, C. Ramseyer, B. Cardey, JBIC J. Biol. Inorg. Chem. 20 (2015) 555-562.

[58] G. Ohanessian, D. Picot, G. Frison, Int. J. Quantum Chem. 111 (2011) 1239-1247.

[59] S. Antony, C.A. Bayse, Inorg. Chem. 52 (2013) 13803-13805.

[60] Gaussian 09, Revision D.01, M. J. Frisch, G. W. Trucks, H. B. Schlegel, G. E. Scuseria, M. A. Robb, J. R. Cheeseman, G. Scalmani, V. Barone, B. Mennucci, G. A. Petersson, H. Nakatsuji, M. Caricato, X. Li, H. P.

Hratchian, A. F. Izmaylov, J. Bloino, G. Zheng, J. L. Sonnenberg, M. Hada, M. Ehara, K. Toyota, R. Fukuda, J. Hasegawa, M. Ishida, T. Nakajima, Y. Honda, O. Kitao, H. Nakai, T. Vreven, J. A. Montgomery, Jr., J. E. Peralta, F. Ogliaro, M. Bearpark, J. J. Heyd, E. Brothers, K. N. Kudin, V. N. Staroverov, R. Kobayashi, J. Normand, K.

Raghavachari, A. Rendell, J. C. Burant, S. S. Iyengar, J. Tomasi, M. Cossi, N. Rega, J. M. Millam, M. Klene, J. E. Knox, J. B. Cross, V. Bakken, C. Adamo, J. Jaramillo, R. Gomperts, R. E. Stratmann, O. Yazyev, A. J. Austin, R. Cammi, C. Pomelli, J. W. Ochterski, R. L. Martin, K. Morokuma, V. G. Zakrzewski, G. A. Voth, P. Salvador, J. J. 
Dannenberg, S. Dapprich, A. D. Daniels, Ö. Farkas, J. B. Foresman, J. V. Ortiz, J. Cioslowski, and D. J. Fox, Gaussian, Inc., Wallingford CT, 2009..

[61] J.P. Perdew, J.A. Chevary, S.H. Vosko, K.A. Jackson, M.R. Pederson, D.J. Singh, C. Fiolhais, Phys. Rev. B 46 (1992) 6671.

[62] J. Tao, J.P. Perdew, V.N. Staroverov, G.E. Scuseria, Phys. Rev. Lett. 91 (2003) 146401.

[63] K. Remya, C.H. Suresh, J. Comput. Chem. 34 (2013) 1341-1353.

[64] T.H. Dunning, J. Chem. Phys. 55 (1971) 716-723.

[65] M.M. Hurley, L.F. Pacios, P.A. Christiansen, R.B. Ross, W.C. Ermler, J. Chem. Phys. 84 (1986) 6840-6853.

[66] W.R. Wadt, P.J. Hay, J. Chem. Phys. 82 (1985) 284-298.

[67] K.B. Wiberg, Tetrahedron 24 (1968) 1083-1096.

[68] R.G. Parr, R.G. Pearson, J. Am. Chem. Soc. 105 (1983) 7512-7516.

[69] R.G. Pearson, Proc. Natl. Acad. Sci. 83 (1986) 8440-8441.

[70] D.H.R. Barton, M.B. Hall, Z. Lin, S.I. Parekh, J. Reibenspies, J. Am. Chem. Soc. 115 (1993) 5056-5059.

[71] C.A. Bayse, R.A. Baker, K.N. Ortwine, Inorganica Chim. Acta 358 (2005) 3849-3854.

[72] M.E. Brezgunova, J. Lieffrig, E. Aubert, S. Dahaoui, P. Fertey, S. Lebègue, J.G. Ángyán, M. Fourmigué, E. Espinosa, Cryst. Growth Des. 13 (2013) 3283-3289.

[73] I.A. Topol, J.R. Casas-Finet, R. Gussio, S.K. Burt, J.W. Erickson, J. Mol. Struct. THEOCHEM 423 (1998) 1328.

[74] D.W. Deerfield II, L.G. Pedersen, J. Mol. Struct. THEOCHEM 419 (1997) 221-226.

[75] D. Fabris, Y. Hathout, C. Fenselau, Inorg. Chem. 38 (1999) 1322-1325.

[76] A.T. Maynard, D.G. Covell, J. Am. Chem. Soc. 123 (2001) 1047-1058.

[77] Y.-M. Lee, C. Lim, J. Am. Chem. Soc. 133 (2011) 8691-8703.

[78] I.L. Alberts, K. Nadassy, S.J. Wodak, Protein Sci. 7 (1998) 1700-1716.

[79] D. Picot, G. Ohanessian, G. Frison, Inorg. Chem. 47 (2008) 8167-8178.

[80] D. Picot, G. Ohanessian, G. Frison, Comptes Rendus Chim. 12 (2009) 546-553.

[81] M. Prigol, C.W. Nogueira, G. Zeni, M.R. Bronze, L. Constantino, Chem. Biol. Interact. 200 (2012) 65-72.

[82] M. Huang, A. Maynard, J.A. Turpin, L. Graham, G.M. Janini, D.G. Covell, W.G. Rice, J. Med. Chem. 41 (1998) 1371-1381.

[83] S. Oka, Y. Shiraishi, T. Yoshida, T. Ohkubo, Y. Sugiura, Y. Kobayashi, Biochemistry (Mosc.) 43 (2004) 16027-16035.

[84] T. Ikegami, I. Kuraoka, M. Saijo, N. Kodo, Y. Kyogoku, K. Morikawa, K. Tanaka, M. Shirakawa, Nat. Struct. Biol. 5 (1998) 701-706. 
Scheme 1. Mechanism of $\mathrm{Zn}^{+2}$ release from ZF proteins by divalent R-S/Se compounds (RE-X) introducing a possible chalcogen bonded intermediate in the initial electrophilic attack. Examples of the sulfen-/selenenating groups $\left(\mathrm{RE}^{+}\right)$are shown in the inset.

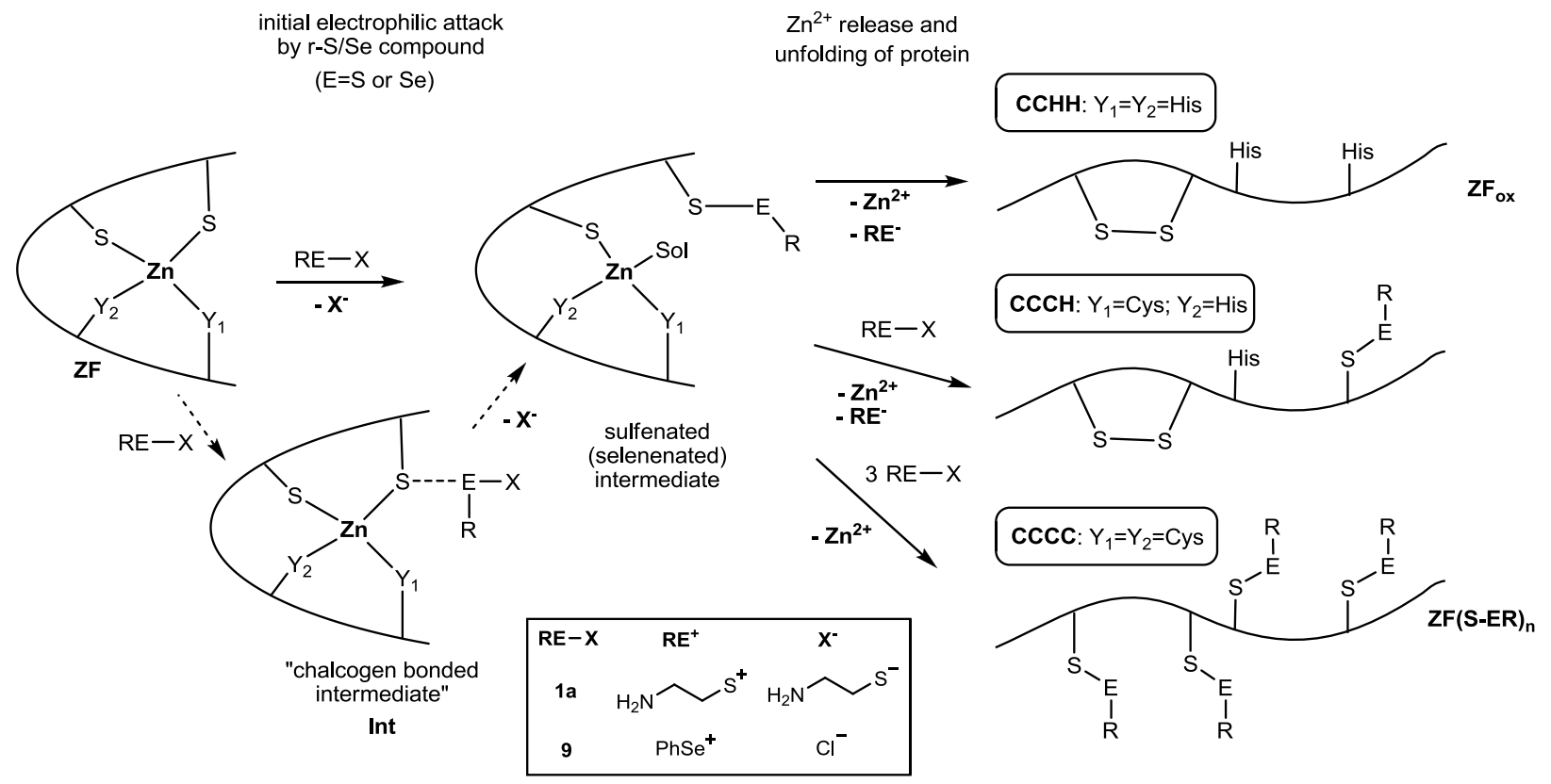

Scheme 2. Bonding models for the $\mathrm{S} / \mathrm{Se}$...S donor-acceptor interaction in the proposed chalcogen bonded intermediate in terms of (a) valence bond theory and (b) molecular orbital theory.

(a)

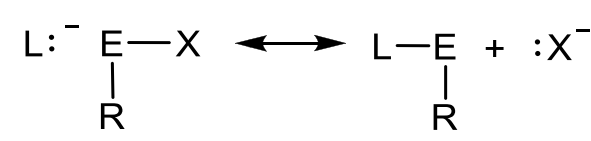

A

B<smiles>[R]C([3H])[I-]C</smiles>

C

(b)

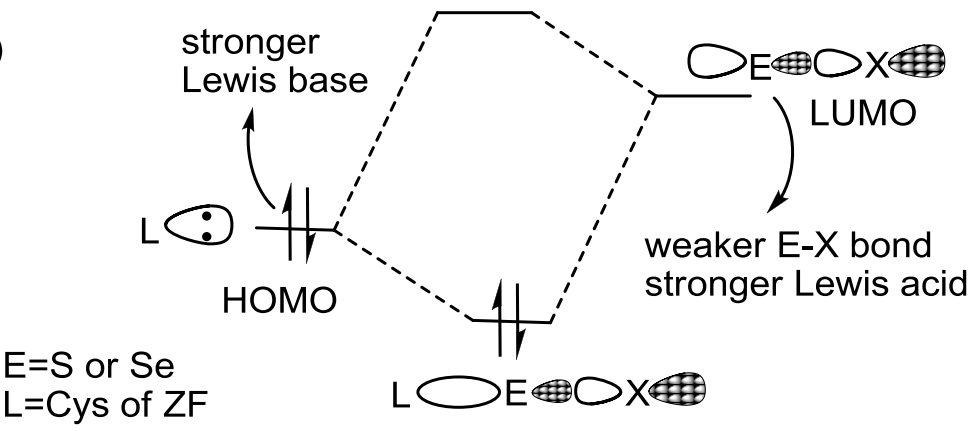




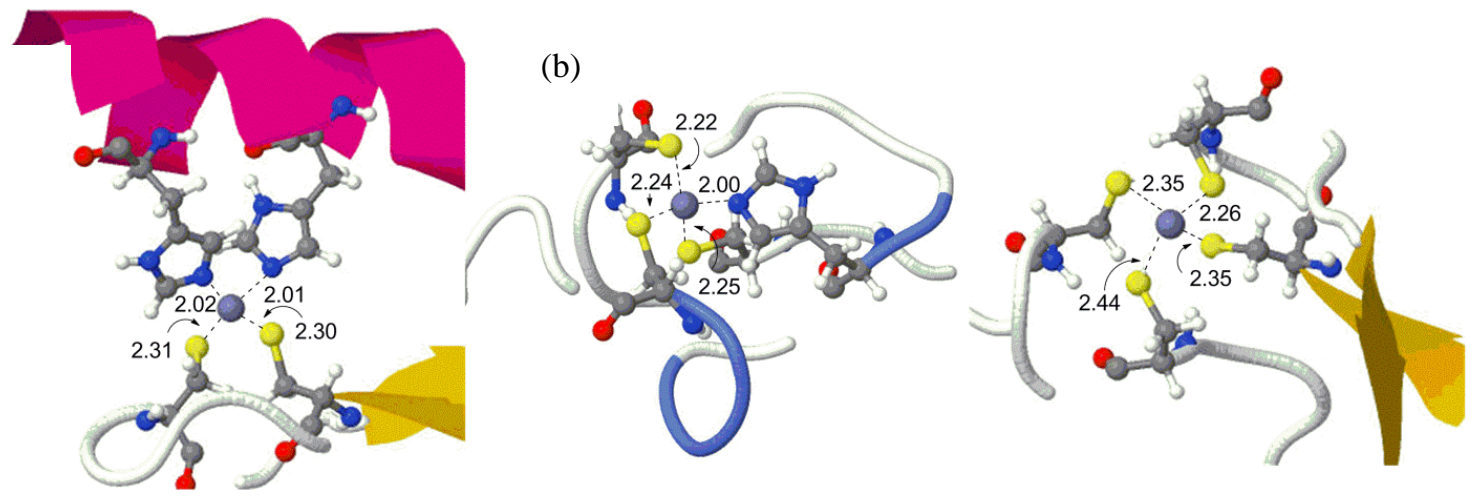

Figure 1. NMR solution structure of each class of zinc-finger proteins: (a) CCHH: transcription factor Sp1 DNA binding domain (PDB 1VA1 [83]; (b) CCCH: NCp7 (PDB 1ESK); (c) CCCC: DNAbinding domain of human repair factor XPA (PDB 1XPA [84]). Bond distances in $\AA$.

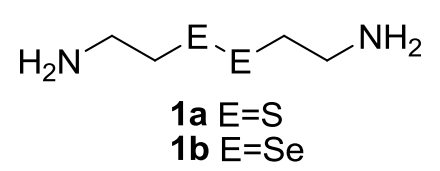<smiles>[R]NC(=O)c1ccccc1C=Cc1ccccc1C(=O)N[R]</smiles>

5a $\mathrm{E}=\mathrm{S}, \mathrm{R}=\mathrm{H}$

5b E=S. R=Ph

$5 c \mathrm{E}=\mathrm{Se}, \mathrm{R}=\mathrm{H}$

5d $E=S e . R=P h$<smiles>[Z]CN(CC)C(=S)SSC(=S)N(CC)CC</smiles>

2<smiles></smiles>

6a $\mathrm{E}=\mathrm{S}, \mathrm{R}=\mathrm{H}$ $6 b \quad E=S, R=P h$ 6c $E=S e . ~ R=H$ 6d E=Se. $R=P h$<smiles>NCCS</smiles>

3<smiles>CCN(CC)C(=S)S</smiles>

4<smiles></smiles>

7a $\mathrm{E}=\mathrm{S}, \mathrm{X}=\mathrm{N}$ $7 \mathrm{~b} E=\mathrm{S}, \mathrm{X}=\mathrm{CH}$ 7c $E=S e . X=N$

7d E $=$ Se. $X=C H$<smiles>NC(CC=CCC(N)C(=O)O)C(=O)O</smiles>

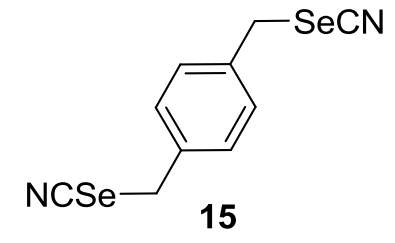

15<smiles>C[CH-]C</smiles>

16a $\mathrm{E}=\mathrm{E}^{\prime}=\mathrm{S}$ $16 \mathrm{~b} E=E^{\prime}=S e$ 16c $E=S, E^{\prime}=S e$

Figure 2. Examples of reducible sulfur and selenium compounds. 

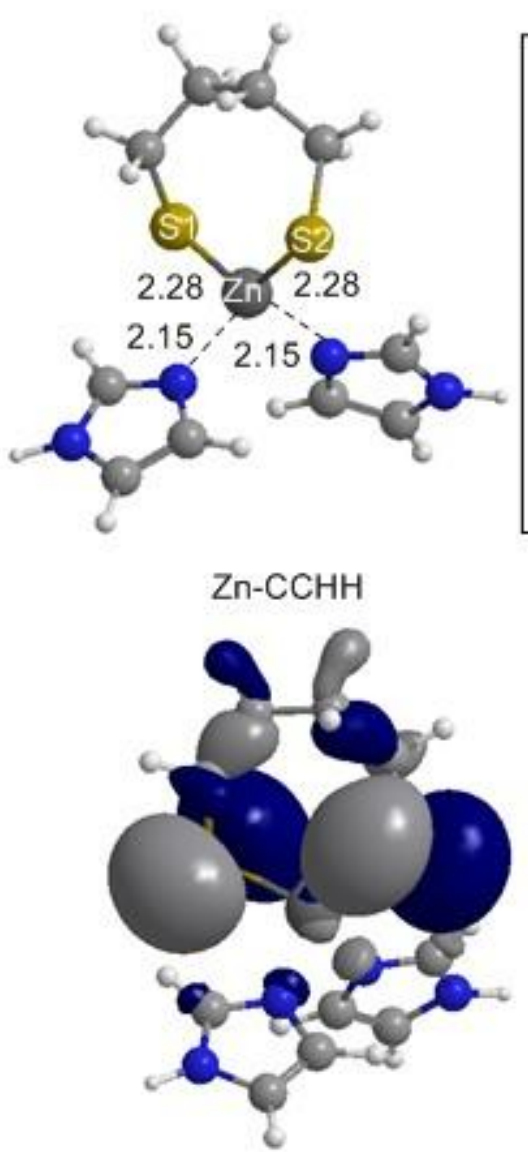

$\mathrm{Zn}-\mathrm{CCHH}$ НОМО

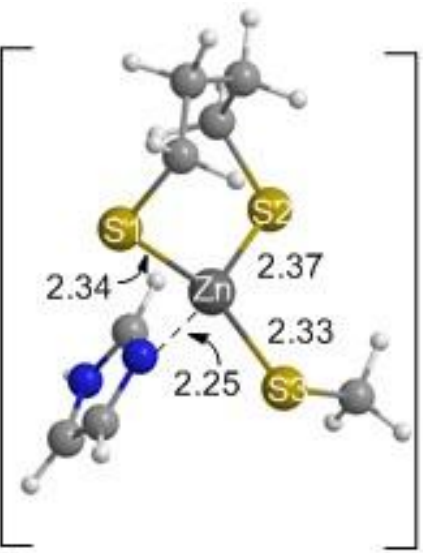

$\mathrm{Zn}-\mathrm{CCCH}$

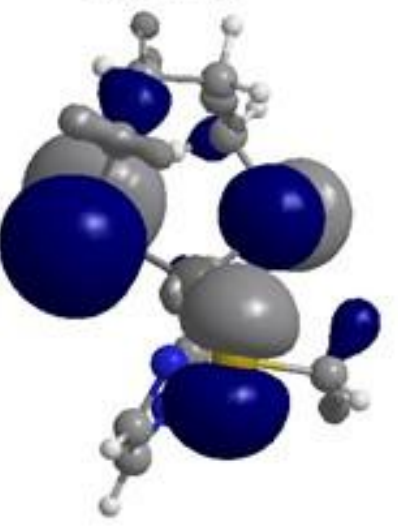

$\mathrm{Zn}-\mathrm{CCCH}$ HOMO
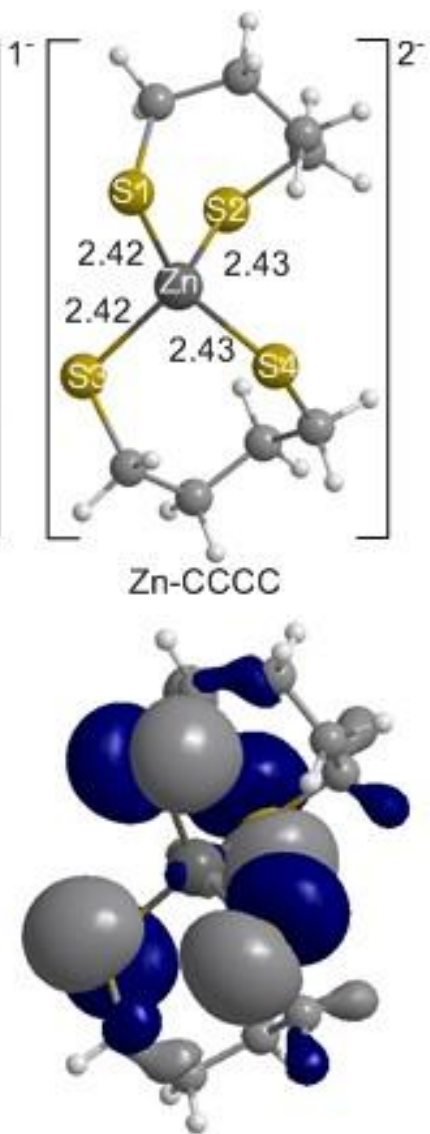

$\mathrm{Zn}-\mathrm{CCCC}$ HOMO

Figure 3. Selected bond distances $(\AA)$ and HOMOs for ZF model complexes $\mathbf{Z n}-\mathbf{C C H H}, \mathbf{Z n}-\mathbf{C C C H}$ and $\mathrm{Zn}-\mathrm{CCCC}$. 


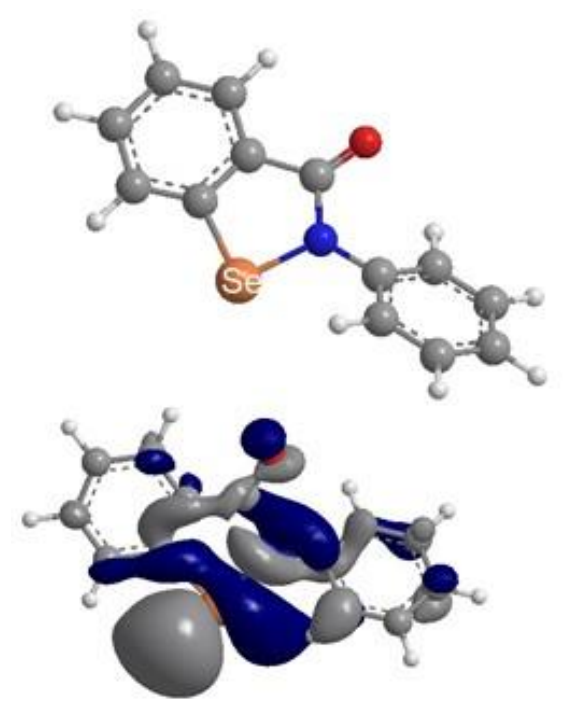

$6 d$

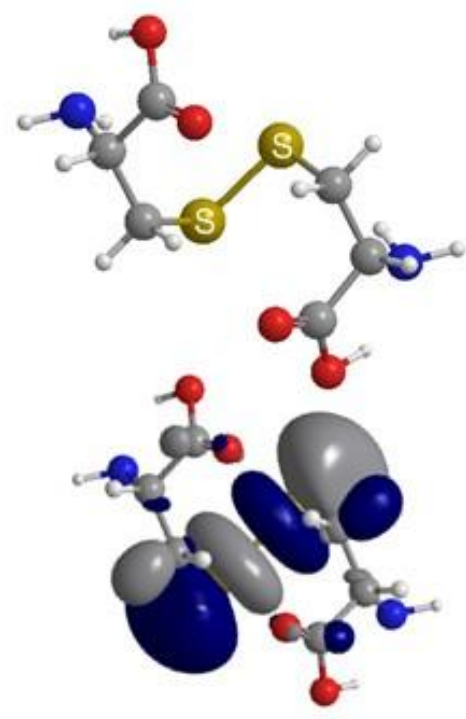

$8 \mathrm{a}$
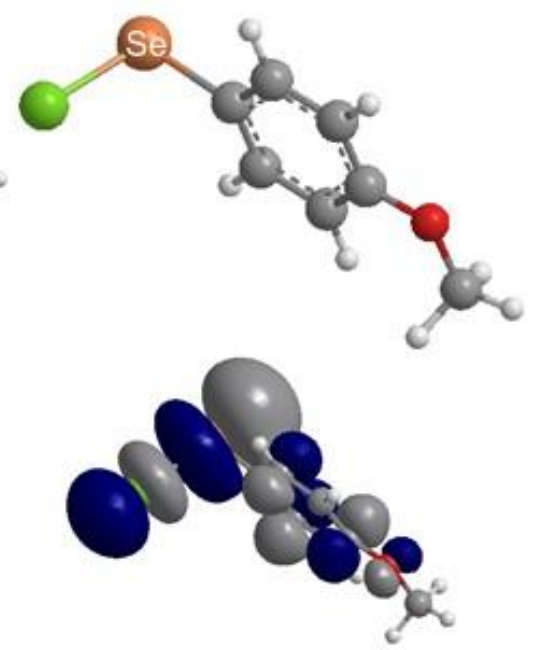

10

Figure 4. Examples of the $\phi^{*}{ }_{\text {Se/s-x }}$ acceptor MOs of $r-S / S e$ compounds.

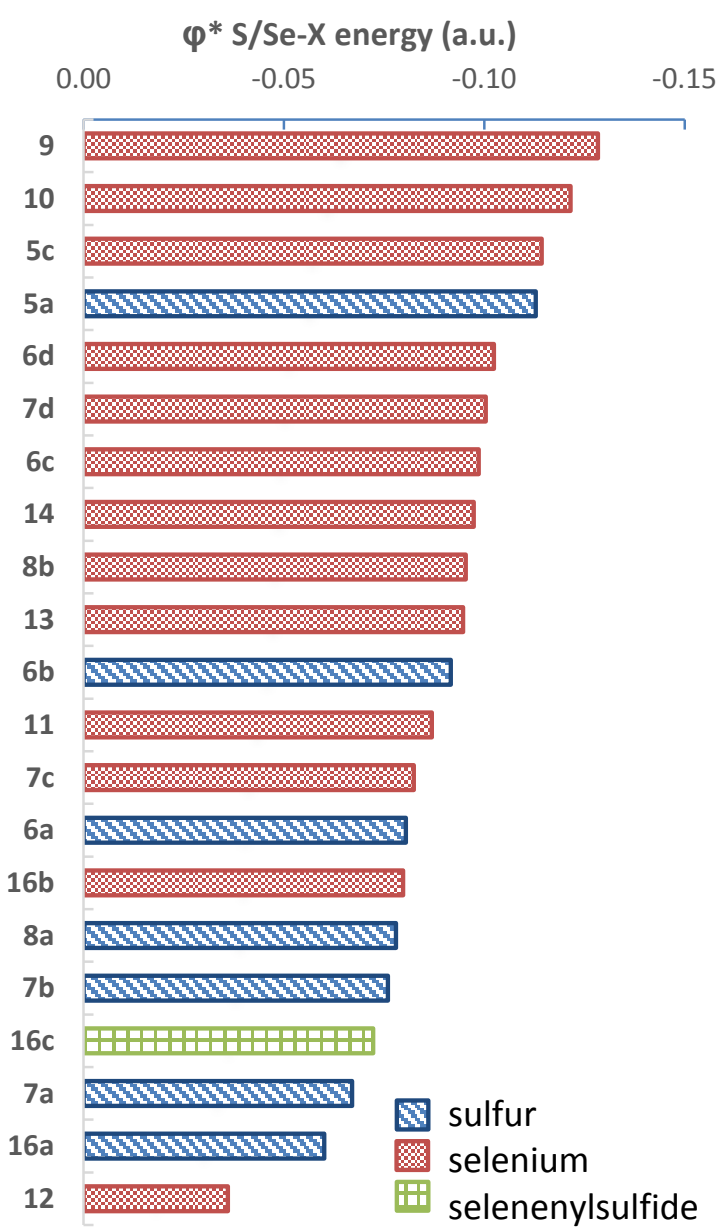

Figure 5. Energies of $\phi^{*}$ s/se-x for $r-S / S e$ compounds 5-14 and 16. 
(a)
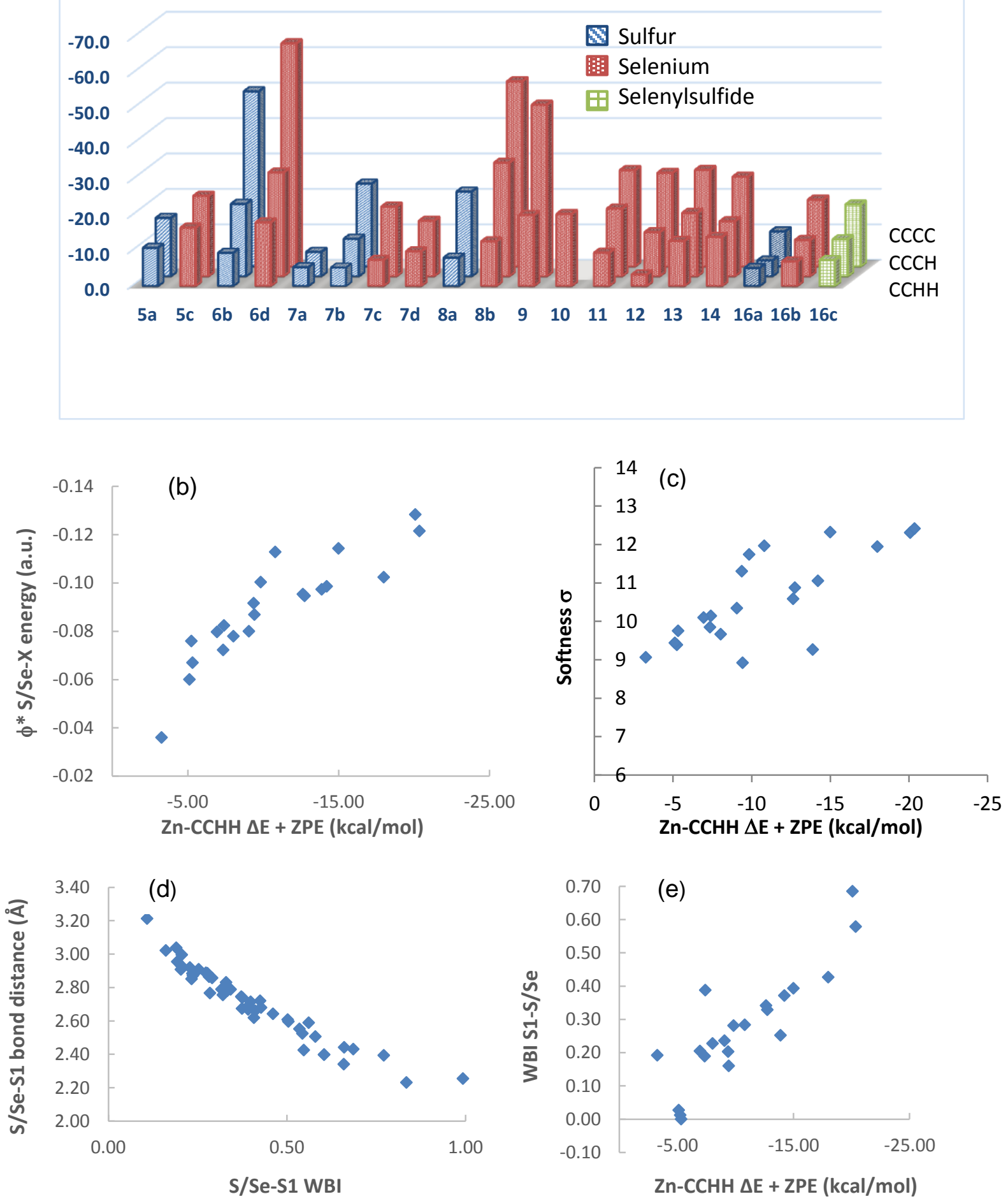

Figure 6. (a) Interaction energies $(\triangle E+Z P E)$ of complexes of $r-S / S e$ compounds 5-14 and 16 with the ZF models. Plots of the (b) $\phi^{*}$ s/se-x energy (a.u.) and (b) softness $\sigma$ versus $\Delta E+Z P E$ for the complexes of 5-14 and $\mathbf{1 6}$ with $\mathbf{Z n - C C H H}$. (d) Correlation between the S1-S/Se bond distance 
and the S1-S/Se WBIs. (e) Plot of the S/Se-S1 WBI versus for $\triangle E+Z P E$ for the complexes of 5-14 and 16 with $\mathrm{Zn}-\mathrm{CCHH}$.

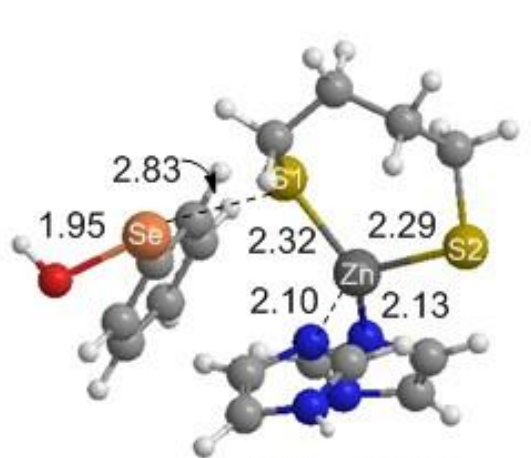

$13-\mathrm{Zn}-\mathrm{CCHH}$

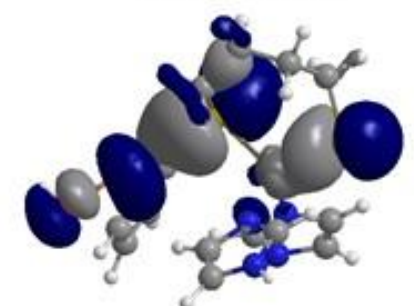

$13-\mathrm{Zn}-\mathrm{CCHH}$ HOMO-2

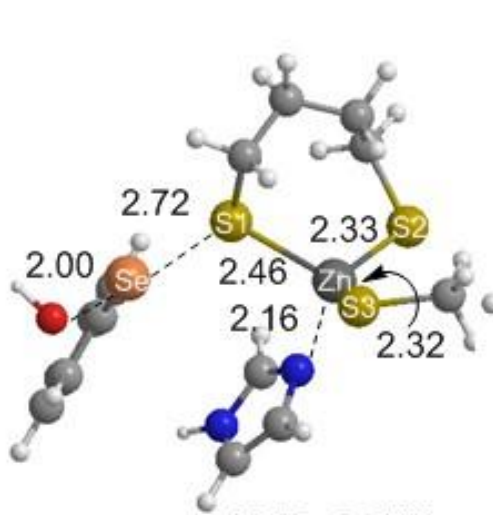

$13-\mathrm{Zn}-\mathrm{CCHH}$

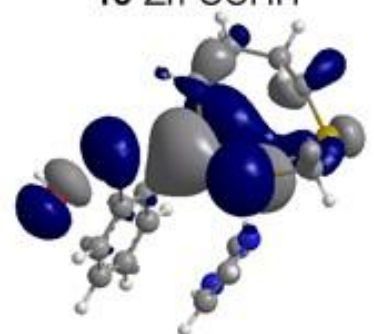

$13-\mathrm{Zn}-\mathrm{CCCH}$ HOMO-4

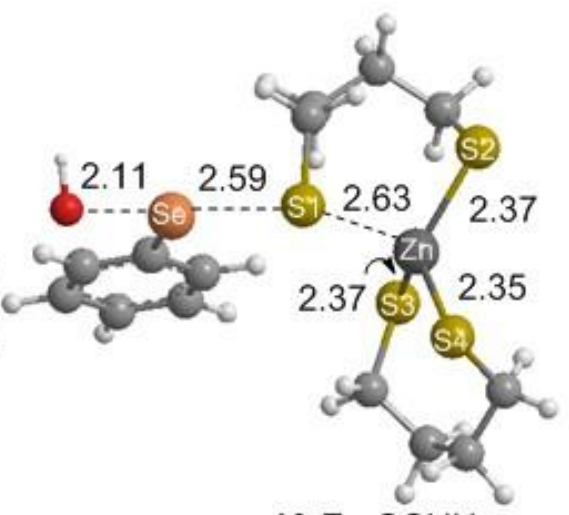

$13-\mathrm{Zn}-\mathrm{CCHH}$

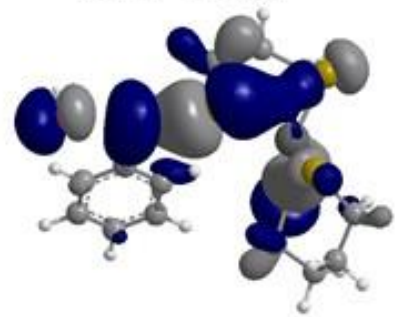

13-Zn-CCCC HOMO-7

Figure 7. Selected bond distances $(\AA ̊)$ and the donor-acceptor $\mathrm{MO}$ for (a) 13-Zn-CCHH, (b) 13$\mathrm{Zn}-\mathrm{CCCH}$, and (c) with 13-Zn-CCCC.

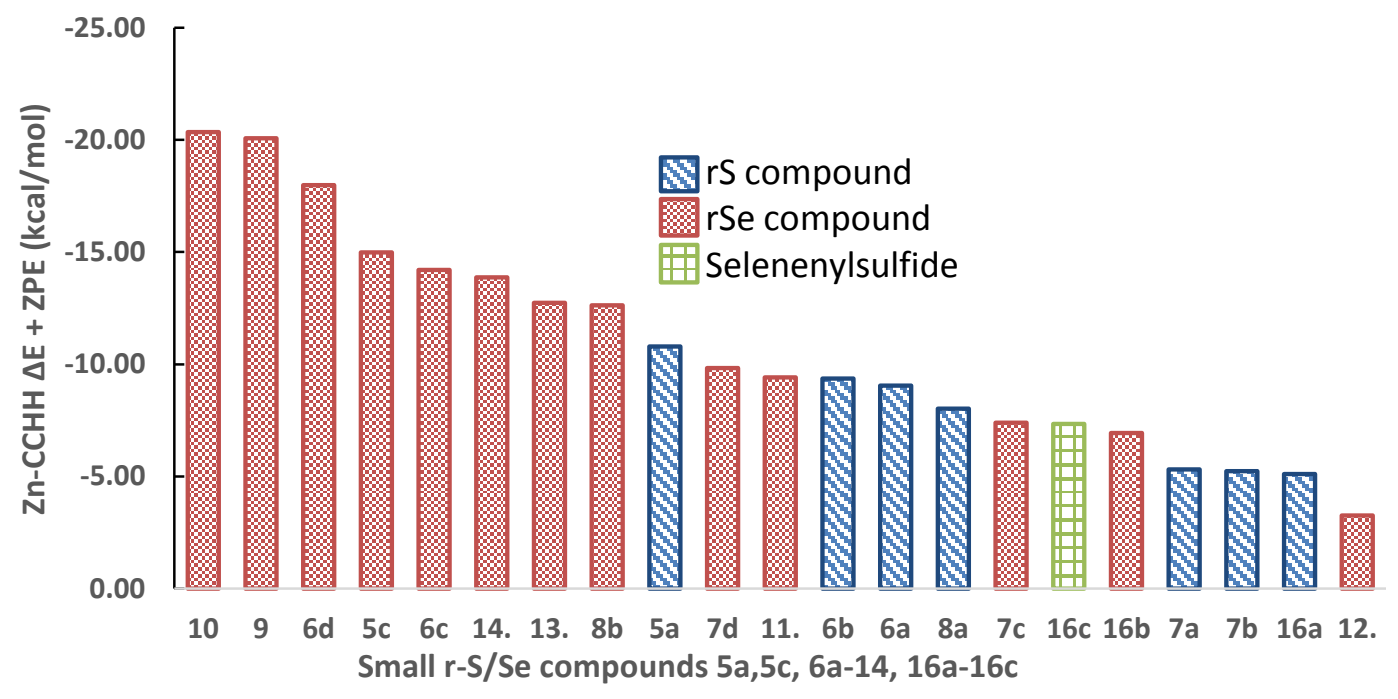

Figure 8. Comparison of $\Delta \mathrm{E}+\mathrm{ZPE}$ for complexes of $5 \mathrm{a}, \mathbf{5 c}, \mathbf{6 a - 1 4}$ and $16 \mathrm{a}-\mathrm{c}$ with $\mathrm{Zn}-\mathrm{CCHH}$. 


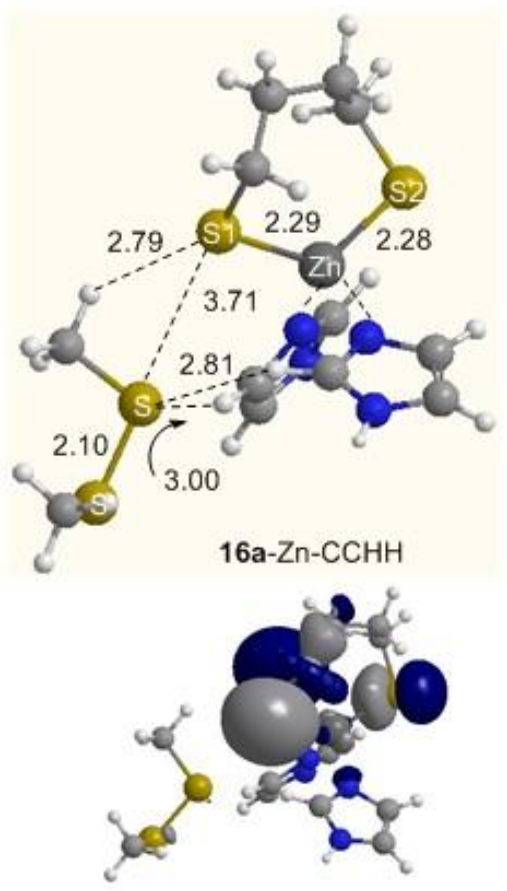

HOMO - 1
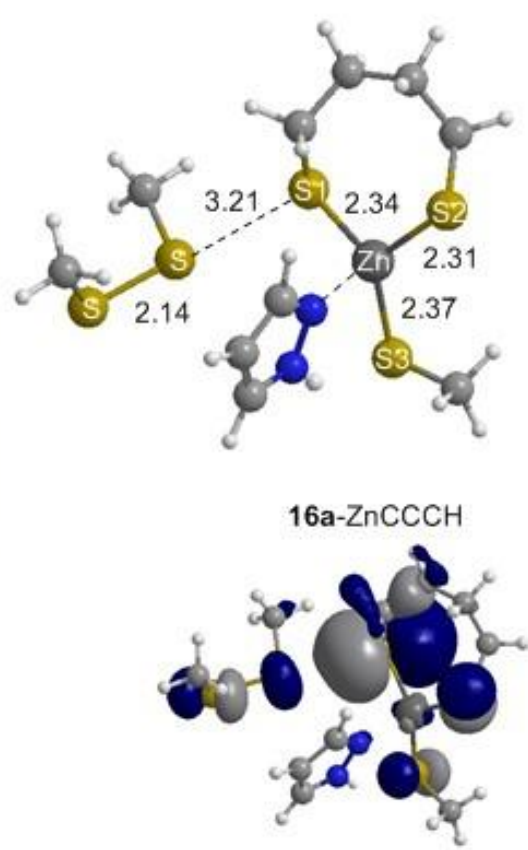

HOMO - 1
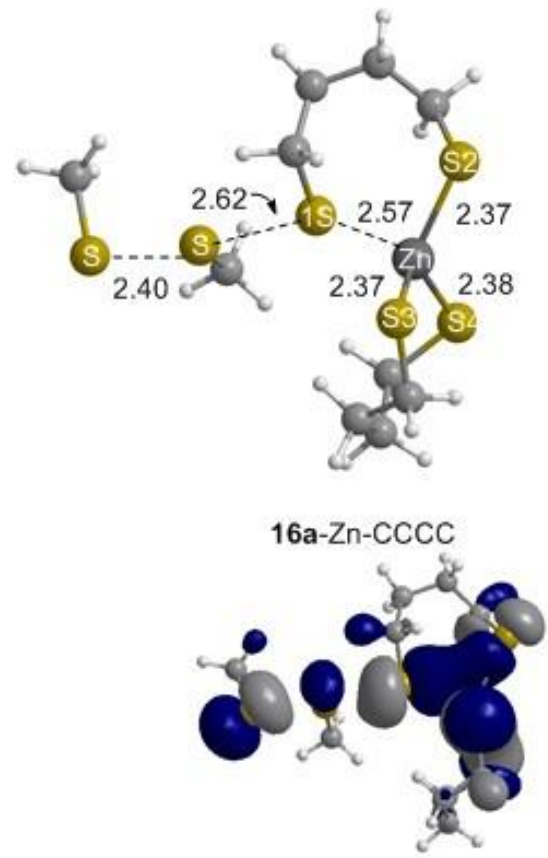

HOMO -6

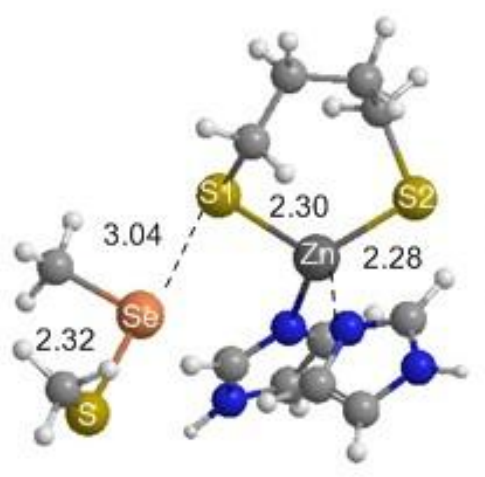

$16 \mathrm{c}-\mathrm{Zn}-\mathrm{CCHH}$

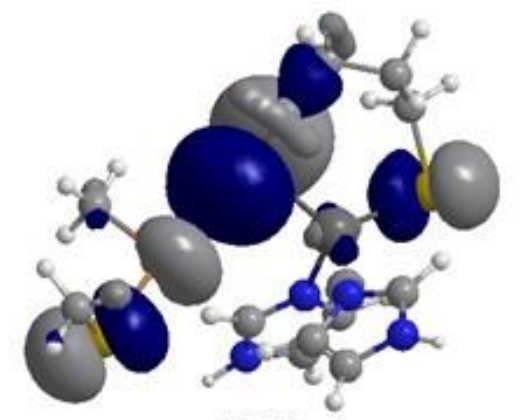

HOMO - 1

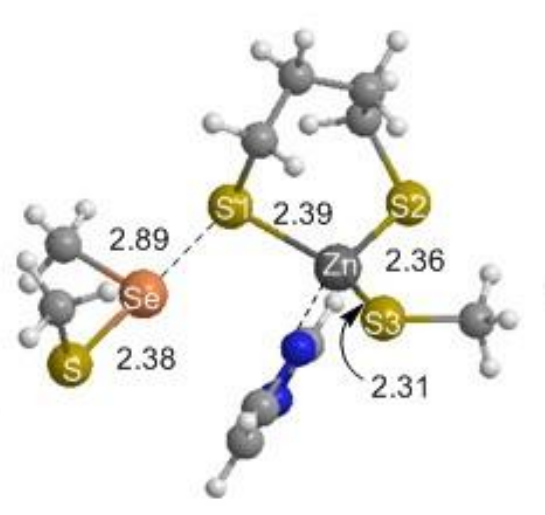

16c- $\mathrm{Zn}-\mathrm{CCCH}$

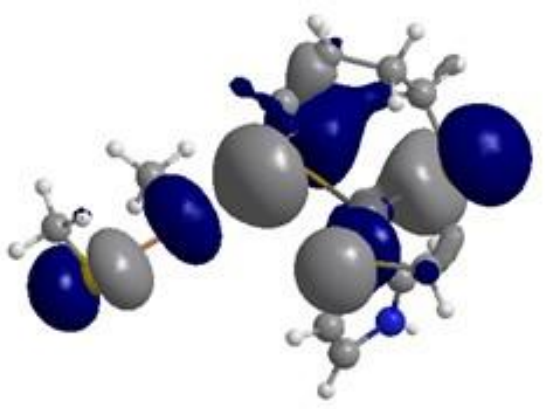

HOMO -2

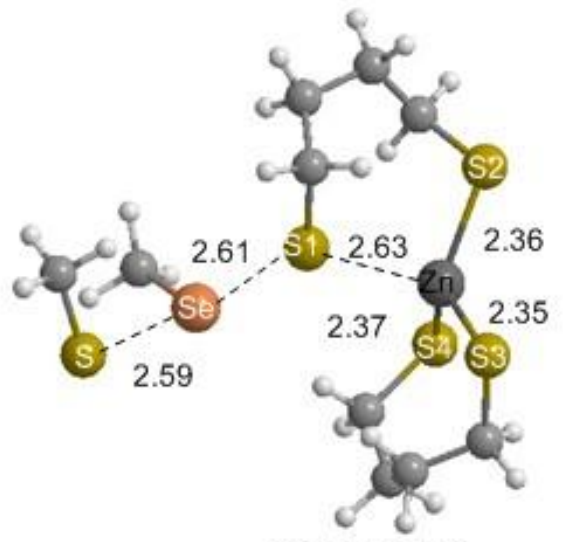

$16 \mathrm{c}-\mathrm{ZnCCCC}$

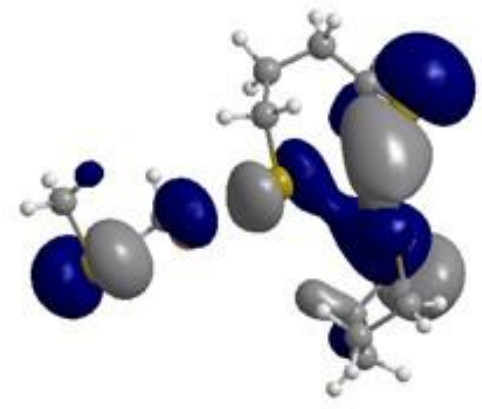

HOMO -4

Figure 9. Selected bond distances $(\AA)$ and donor-acceptor $M O$ for complexes of 16a and 16c with $\mathbf{Z n - C C H H , ~} \mathbf{Z n}-\mathbf{C C C H}$ and $\mathbf{Z n - C C C C}$. 


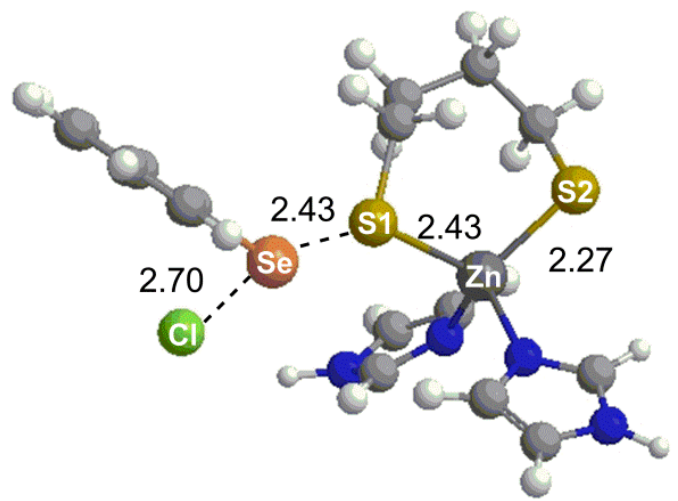

9-Zn-CCHH

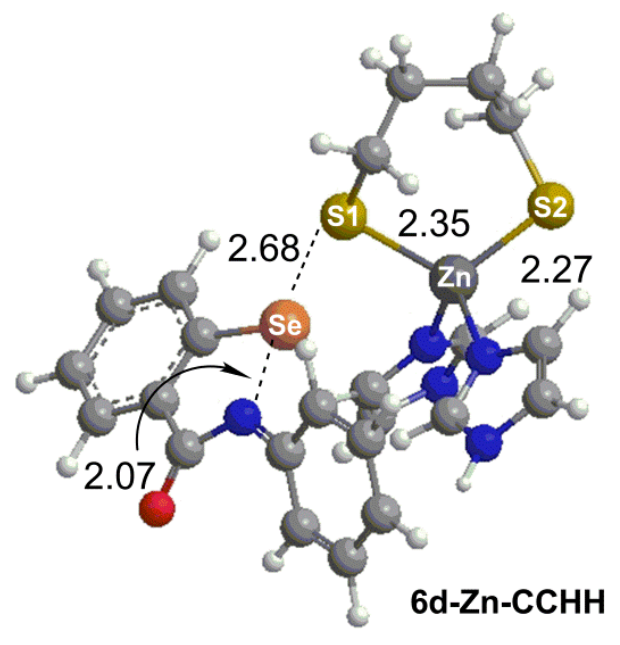

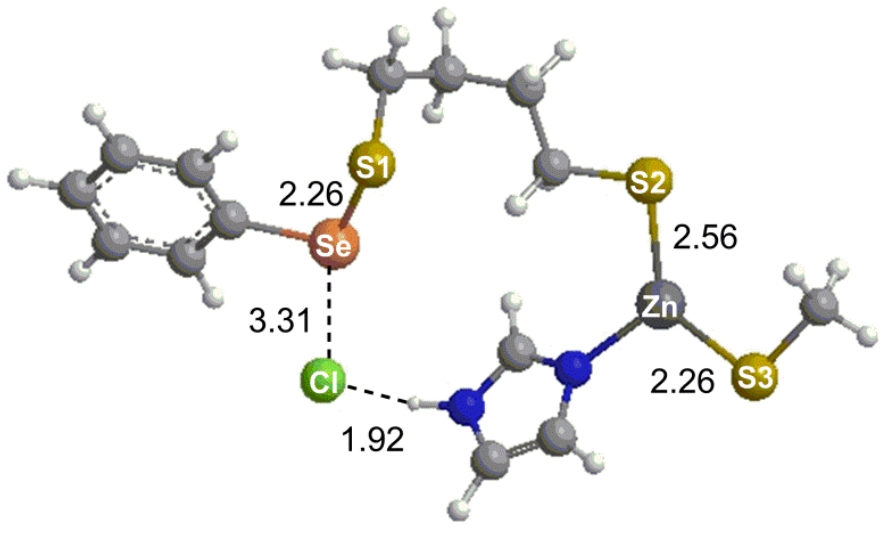

$9-\mathrm{Zn}-\mathrm{CCCH}$

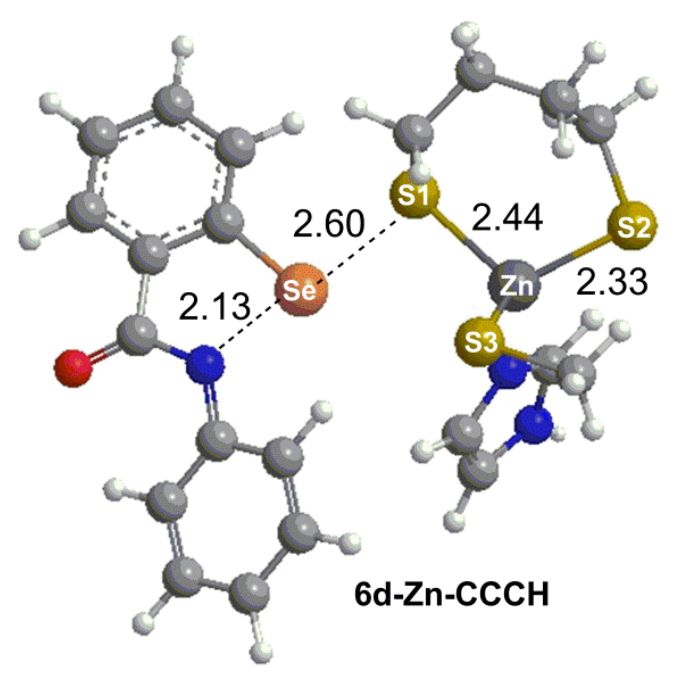

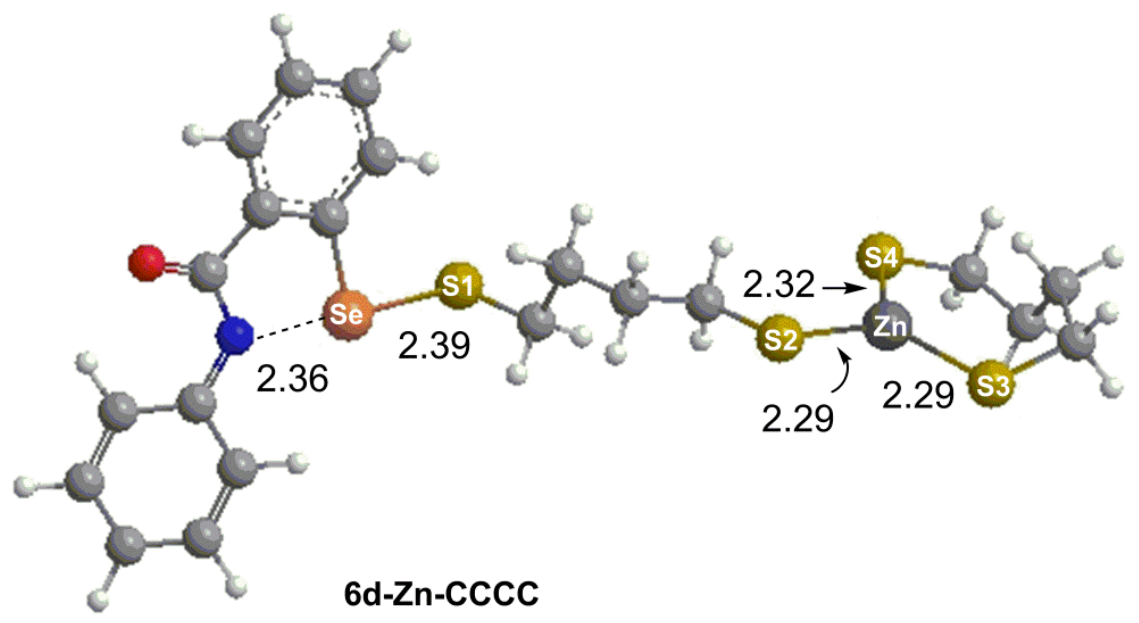

Figure 10. Selected bond distances $(\AA)$ and donor-acceptor MOs for the interaction of $\mathbf{9}$ and $\mathbf{6 d}$ with $\mathrm{Zn}-\mathrm{CCHH}, \mathrm{Zn}-\mathrm{CCCH}$ and $\mathrm{Zn}-\mathrm{CCCC}$. 
Table 1. DFT(PW91TPSS) frontier orbital energies (a.u.), Zn-S Wiberg bond indices (WBIs) and NPA charges for ZF model complexes. See Figure 3 for atom labels.

\begin{tabular}{|c|c|c|c|c|c|c|c|c|c|c|c|c|}
\hline Model & HOMO & IP & $\sigma$ & $\begin{array}{c}\text { WBI } \\
\text { Zn-S1 }\end{array}$ & $\begin{array}{c}\text { WBI } \\
\text { Zn-S2 }\end{array}$ & $\begin{array}{c}\text { WBI } \\
\text { Zn-S3 }\end{array}$ & $\begin{array}{c}\text { WBI } \\
\text { Zn-S4 }\end{array}$ & q S1 (e) & q S2 (e) & q S3 (e) & q S4 (e) & $\mathrm{q} Z \mathrm{Zn}(\mathrm{e})$ \\
\hline $\mathrm{Zn}-\mathrm{CCHH}$ & -0.147 & -0.008 & 14.351 & 0.735 & 0.735 & & & -0.379 & -0.379 & & & 0.674 \\
\hline $\mathrm{Zn}-\mathrm{CCCH}$ & -0.025 & 0.068 & 21.532 & 0.674 & 0.634 & 0.694 & & -0.393 & -0.414 & -0.382 & & 0.535 \\
\hline $\mathrm{Zn}-\mathrm{CCCC}$ & 0.089 & 0.121 & 62.124 & 0.596 & 0.590 & 0.596 & 0.590 & -0.414 & -0.423 & -0.414 & -0.423 & 0.424 \\
\hline
\end{tabular}

